Georgia State University

ScholarWorks @ Georgia State University

$9-1-2017$

\title{
How Capitalism Endogenously Creates Rising Income Inequality and Economic Crisis: The Macro Political Economy Model of Early Industrial Relations
}

\author{
Bruce E. Kaufman \\ Georgia State University, bkaufman@gsu.edu
}

Follow this and additional works at: https://scholarworks.gsu.edu/uwrg_workingpapers

\section{Recommended Citation}

Kaufman, Bruce E., "How Capitalism Endogenously Creates Rising Income Inequality and Economic Crisis: The Macro Political Economy Model of Early Industrial Relations" (2017). UWRG Working Papers. 109.

https://scholarworks.gsu.edu/uwrg_workingpapers/109

This Article is brought to you for free and open access by the Usery Workplace Research Group at ScholarWorks @ Georgia State University. It has been accepted for inclusion in UWRG Working Papers by an authorized administrator of ScholarWorks @ Georgia State University. For more information, please contact scholarworks@gsu.edu. 


\section{W. J. Usery Workplace Research Group Paper Series}

Working Paper 2017-9-1

September 2017

How Capitalism Endogenously Creates Rising Income Inequality and Economic Crisis: The Macro Political Economy Model of Early Industrial Relations

Bruce E. Kaufman

Georgia State University

ANDREW Young SchoOL 
How Capitalism Endogenously Creates Rising Income Inequality and Economic Crisis:

The Macro Political Economy Model of Early Industrial Relations

\author{
Bruce E. Kaufman \\ Department of Economics, Georgia State University, Atlanta GA 30303 USA \\ Email: bkaufman@gsu.edu
}

September 8, 2017

Forthcoming: Industrial Relations 
How Capitalism Endogenously Creates Rising Income Inequality and Economic Crisis:

The Macro Political Economy Model of Early Industrial Relations

"The forces of equilibrium are real, but they are only half the story. There are also forces making for breakdown. And intellectual interest in or emotional enthusiasm for the smooth-running features of competitive capitalism should not blind us to the other side of the story." Paul Douglas (1935a:85).

"Given a political system that is so sensitive to moneyed interests, growing economic inequality leads to a growing imbalance of political power, a vicious nexus between politics and economics." Joseph Stiglitz (2012: xx).

Introduction

The two epigraphs come from books separated by nearly eighty years, Controlling Depressions by Paul Douglas (1935) and The Price of Inequality by Joseph Stiglitz (2012). Although one author is a labor economist and professor of industrial relations (his position title at Chicago) and writes about the Great Depression of the 1930s, and the other is a Nobel laureate economic theorist and writes about the World Economic Crisis of 2008-2009, their respective messages are connected parts of an institutionalist theory of endogenous income inequality and macroeconomic crisis.

Both men argue that a free-market economy, through a nexus of interacting economic and political forces, internally generates rising income and wealth inequality, aggregate demand/supply imbalance, and risk of economic and financial collapse. Stiglitz cites, for example, "adverse dynamics" and "vicious circles" (p. 82) and says, "unbalanced politics driven by extremes of inequality leads to instability" (p. 89). Similarly, Douglas says, "There are present in our economic system latent tendencies which may, and more or less periodically do, result in a cumulative disequilibrium" (p. 85). To combat this destabilizing dynamic, both economists advocate an agenda of institutional and policy reforms that redistribute economic and political power to labor and the lower-middle classes, including initiatives that strengthen labor laws, collective bargaining, social safety net programs, education and training opportunities, and full-employment 
fiscal/monetary policies. Douglas and Stiglitz are both aware their diagnoses and solutions are likely to get a failing grade when viewed through the lens of orthodox theory but to them the theory is a "romantic daydream" (Douglas, p. 249) and "pleasant fantasy" (Stiglitz, p. 116).

Papers with an explicit macroeconomics focus are unusual in an industrial relations (IR) journal. However, few labor-related topics today figure as prominently in academic research and political/policy debates as the causes of macro-level wage stagnation, rising income inequality, and anemic employment and GDP growth (Freeman 2007; Palley 2012; Wisman 2013; Piketty 2013). These trends, for example, were at center stage in the 2016 Presidential election, particularly as the political parties responded to growing middle-class anger and frustration at the disappearance of rising living standards and secure well-paying jobs, and brought out a stream of conflicting diagnoses and solutions from right- and leftoriented think tanks (e.g., Sherk 2013; Bivens and Mishel 2015). These trends have also been identified as causal factors in the labor market collapse of the Great Depression of the 1930s and near-collapse in World Financial Crisis of 2008-2009. Also germane for an industrial relations audience is the little-known fact that the macroeconomic connection between wages, inequality, and economic cycles and crises was the leading research topic in the early American IR field from its founding in 1918-1920 through the first phase of the New Deal in the mid-1930s. In this area the three most important American contributors were institutional labor economists John Commons, Paul Douglas, and Sumner Slichter, while in Britain the major contributors were Sidney and Beatrice Webb, John Hobson, G.D.H. Cole, and William Beveridge. Although some second-order differences separate their respective models and policy recommendations (the British were more left-radical than the Americans), as a group these IR pioneers carved out a distinctive theoretical and policy program broadly in the middle between the neoclassical free-market and laissez-faire right and Marxian socialist and central planning left.

Given the current-day importance of the income inequality topic, and plethora of competing and sometimes incommensurate explanations, this paper makes a contribution by going back to the institutional economics/industrial relations (IEIR) literature of the 1920s-1930s, with primary focus on the 
American team of Commons, Douglas, and Slichter (CDS), and analytically represents their theory of endogenous wage stagnation, rising income inequality, and macroeconomic crisis. Three research questions are the center of analysis: (1) does a neoliberal, free market economy have a built-in propensity to generate a secular increase in income inequality and, if so, how and why?, (2) if it does, can an economy maintain long-run macroeconomic demand/supply (DS) balance and full-employment GDP growth as real wages stagnate and labor's income share declines?, and (3) similarly, what role do IR institutions and policies play in the inequality-crisis scenario and, in particular, how can they reduce or prevent the trend toward inequality and stagnation/crisis? The answers to these questions, which boil down to Yes, No, and Share Productivity Gains with Labor, are worked out by formalizing into diagrams the key ideas of this early IEIR literature.

The only analytical requirement for readers is familiarity with aggregate demand/aggregate supply (AD/AS) analysis from basic economics (e.g., Krugman and Wells 2015) and patience to work through two diagrams with numerous letters and arrows. The paper develops the theory ideas from early IR largely in the historical context of the 1920s-1930s but at the end applies the insights and policy recommendations to today's economy. Although the analysis is largely developed with reference to the American situation, where the economy is relatively free market/neoliberal and inequality trends are likewise most pronounced, a number of other countries have rising income inequality for which these ideas also have application (Berlingieri, Blanchenay, and Criscuolo 2017).

Overview: Empirical Inequality Trends and Competing Theoretical Perspectives

Before getting into the specifics of IEIR theory it is helpful to put the central research questions into an empirical and theoretical context.

Figure 1 shows the growth in net productivity (output per employee hour net of depreciation) and mean and median real hourly compensation (wages and benefits) for private sector non-supervisory employees in the U.S. from 1973 to 2014 (Bivens and Mishel 2015). In the preceding period of 1947 to 1973, real 
compensation grew modestly faster than productivity (2.7\% vs. 2.1\%) but then between 1973 and 2014 the relationship reversed (1.0\% vs. 1.7\%). More eye-catching, after 1973 mean real compensation grew $42.5 \%$ but median real compensation by only $8.7 \%$, indicating that most of the compensation growth was for a small group of very high earners (substantially pulling up the mean). Thus, from 1947 to 1973 all the productivity gains generated by economy were passed into higher real wages; after 1973 only 15\% was passed on, mostly bunched in the late 1990s when the economy was near full employment. If the years 1995-2000 are taken out, real median compensation from 1973 to 2014 was essentially flat $(\uparrow 2.6 \%)$. When the data are disaggregated by industry, the decoupling between productivity growth and real wage growth is most stark in the manufacturing sector. Diagrammatically, the result is emergence and growth of a productivity-wage cone.

Countries such as Australia, Britain, Canada and Germany have also had a decoupling of productivity and real wage growth although the cone is more recent and smaller. Trends within and across countries are also noticeably affected by choice of productivity, compensation, and price measures (Freeman 2007).

Figure 2 shows the share of pre-tax national income going to the top $1 \%$ of households from the mid1910s to 2010 in Australia, Canada, Great Britain, and United States (Osberg 2014). Income inequality increased in the U.S. over the early $20^{\text {th }}$ century, peaked in 1928 just before the onset of the Great Depression, and after World War II fell to much lower levels until the late 1970s. Then, timed with the Reagan-Thatcher shift to free market neoliberalism, inequality began an upward climb that continues to the present time and reached the 1920s peak in the early 2010s. Similar trends occur in the other three countries, although less accentuated and with somewhat different-timed peaks. Although not shown in Figure 2, rising income inequality in the US has also been accompanied by rising wealth inequality, leading to these types of disparities: in 2013 , the top $1 \%$ of households had average income of $\$ 1,679,00$ and average net worth of $\$ 18,623,000$; the top $20 \%$ had $\$ 257,200$ and $\$ 2,260,300$, respectively; while the bottom $40 \%$ had $\$ 20,300$ and $-\$ 10,300$ (Domhoff 2017: Table 1). 
[Insert Figures $1 \& 2$ Here]

Clearly there are winners and losers from these trends. For example, had the 1948-1972 pattern of income inequality and labor force participation continued through 1973-2013, the median household would have received 18 percent (\$9000) more income (Council of Economic Advisors 2015: 33). In terms of the overall performance of the economy, however, does a different split of the pie effect the size of the pie? The answer is: it depends.

When looking at the trends in Figures 1 and 2, care must be taken to distinguish between cause and effect. That is, are the trends in wage stagnation and rising inequality causes of unbalanced growth and eventual crisis or are they the induced effects (Slichter 1936: 200). Also, the answer depends on which school of economics is consulted (Murphy and Topel 2016; Palley 2016). Illustratively, Stiglitz (2012: 243) asserts, "the standard macroeconomic models don't even recognize that the distribution of income matters" and Douglas (1935b: 107) observes, “The economists of the so-called 'orthodox' school have tended to content themselves with Say's dictum .... [and] therefore looked with more or less contempt upon the theory that depressions are caused by the masses not possessing sufficient purchasing power."

Rephrased, Douglas and Stiglitz are saying that in conventional economics 'distribution doesn't matter' for explaining aggregate DS equilibrium and boom-bust cycles. As examples, Christina Romer (2013), former chair of President Obama's Council of Economic Advisers, in a paper "Lessons of the Great Depression for Policy Today" does not mention the wage-productivity nexus or rising income inequality, nor are these topics mentioned by Janet Yellen, chair of the Federal Reserve Bank, in an assessment of the 2016 growth outlook for the American economy (Yellen 2016). Similarly, Nobel-laureate Edward Prescott (1999), in an article "Some Observations on the Great Depression," argues (p. 28), "The capitalistic economy is stable, and absent some change in technology or the rules of the economic game, the economy converges to a constant growth path with the standard of living doubling every forty years." He concludes (p. 26) that the cause of the Great Depression was not too much income inequality but 
wrongheaded government policies, such as programs by Presidents Hoover and Roosevelt to stimulate demand by maintaining/raising wage rates. Actually, in neoclassical growth models lower wages and higher income inequality are pro-growth because they promote larger saving-investment and faster increase in the amount of capital $(\mathrm{K})$ for input in the nation's production function.

Mainstream economists tend to steer clear of the income inequality $\rightarrow$ demand failure $\rightarrow$ crisis topic because the theory is regarded as unacceptably heterodox with political-ideological implications too critical/left. Prescott (1999:30), for example, refers to this research stream as “the Marxian view;" former Secretary of Labor Robert Reich (2012:6) remarks, "I used to be called a class warrior for even raising the subject of widening inequality,' while Chicago Nobelist Robert Lucas (2004: 7) dismisses the topic with the observation, "Of the tendencies that are harmful to sound economics, .... in my opinion the most poisonous, is to focus on questions of distribution." The mainstream's acceptable outer boundary on the inequality topic is illustrated by Jason Furman, chair of Obama's Council of Economic Advisors. Following Stiglitz, he argues that "the assumption of a perfectly competitive marketplace is often misguided" (Furman and Orszag 2015: 1), highlights growing firm-level monopoly power, declining labor mobility, and growing inequality in the division of rents as causes of the inequality trend, but does not take the last and biggest step and causally link inequality to macroeconomic (mal)performance.

The neoclassical second welfare theorem and Say's Law doctrine in macroeconomics give theoretical justification to the mainstream's 'distribution doesn't matter' position. The second welfare theorem states that in a perfectly competitive economy the attainment of efficiency is independent of the distribution of endowments and income (Mas-Colell, Whinston, and Green 1995). Say's Law states that in a competitive market economy it is logically impossible to have a general condition of overproduction (a supply glut), and its converse of demand deficiency, because prices for commodities and factor inputs fall until all markets clear and AD = AS (Keynes 1936; Davidson 2007; Lavoie 2014). The implication of these two propositions is that the empirical trends in wage stagnation and income inequality in Figures 1 and 2 are irrelevant to attainment of full-employment GDP. Thus, if the top decile of households gets most of the 
income then the economy produces more Mercedes, cosmetic surgery, private schooling, and capital/investment goods (because the rich save more $\rightarrow$ lower interest rates $\rightarrow$ larger share Investment/GDP) but if the bottom decile gets more of the income then the economy produces more Chevrolets, hot dogs, vinyl handbags, and fewer capital goods. Thus, income distribution affects the composition of GDP, represented by alternative points on the production possibility frontier, but not the economy's automatic price-driven gravitation to it.

A long line of non-orthodox economists claim, on the other hand, that 'distribution matters' for aggregate DS balance (Bleaney 1976; Devine 1983; Brown 2005; Wisman 2013; Lavoie and Stockhammer 2013). Commons (1934a: 348-66, 876-877; 1934b: 60) claims that all schools of modern economics are rooted in Adam Smith but then split into orthodox and heterodox branches in the late 1810s based on the dispute between Ricardo and Malthus over method (abstract vs. realist), theorizing the human agent (strong rationality/individualist vs. limited rationality/social), and validity of Say's Law and invisible-hand equilibrium process. Orthodox economics follows in the tradition of Ricardo and original institutional economics and Keynesian economics follow in the tradition of Malthus, and his contemporary Sismondi. (Marx takes a conflicted position, denigrating Malthus but following him on Say's Law). Both Commons and Keynes reject the Say's Law and invisible hand doctrines and therefore fall in the Malthus-Sismondi line (Atkinson and Oleson 1998; Kaufman 2012), which Keynes (1936: 340) refers to as the "brave army of heretics.” On this matter, Douglas (1935b: 117) observes,

And, since the 'orthodox' have dominated the schools, the result has been that the doctrines of Owen, Malthus, Sismondi, Marx, Rodbertus, Hobson, and C.H. Douglas have been relatively ignored by those who regard themselves as the economic literate. Instead the orthodox have emphasized the theory that there is an almost precise balancing between the forces of production and consumption, and by reiterating the theory of equilibrium have ignored the fact of breakdowns.

Regarding the self-correcting property of markets, and the operation of a presumed invisible hand, IEIR economists are unanimous in rejecting these ideas. Commons states, for example, "There is no invisible hand about it, no natural equilibrium of forces of nature that augments the national wealth by mere 
unguided self-interest" (1923: 116-17) and "Modern capitalistic industry has proved that there is universal overproduction and unemployment... This was impossible under the older molecular theories of demand and supply" (1934a: 892). Similarly, the Webbs (1923: 142) claim, “There is no such 'invisible hand' as Adam Smith romantically suggested" and John Dunlop (1944:228) asserts in his first book, "The automatic pricing mechanism as model or institution in the labor market is dead." The 'no invisible hand' thesis is also the central proposition in Keynes' General Theory (Davidson 2007; Kaufman 2012) and Stiglitz follows Keynes in declaring, "There is no invisible hand" (The Guardian, December 20, 2002).

The 'no invisible hand' proposition means IEIR, (original) Keynes, and post-Keynesians - recently synthesized into a macro school of thought called 'Post-Keynesian Institutionalism' (Whalen 2008) -are doubly heterodox for they deny not only the second welfare theorem but also the first welfare theorem, stating that a competitive market system yields Pareto efficient outcomes (Mas-Colell, Whinston, and Green 1995). This dissenter's position naturally leads IEIR and fellow economists to also deny the theorem's central policy implication, which is laissez-faire and non-intervention (Mas-Colell, Whinston, and Green 1995: 524). For example, Slichter (1934) argues, "Since ordinary market processes do not produce the adjustments needed to stabilize production and employment,...this means that the government...needs to assume the new function of economic manager" (p. 213). Government, therefore, has the task of acting as the coordinating visible hand of the economy, exerting social control at strategic places to obtain what Commons (1934a: 120) calls a ‘managed equilibrium' with ‘reasonable values' (pp. 682-83).

The IEIR position is that a free-market capitalist system typically operates inside the economy's production possibility frontier and is prone to large and disruptive expansions and contractions with threat of periodic depression and breakdown. One of the contributing factors to the instability and breakdown of the system is an endogenous propensity toward failure of wages to rise in line with productivity, leading to increasing income inequality and DS imbalance. Douglas (1935b: 117) concludes, for example, 
the chain of reasoning would therefore seem to be fairly clear, that a failure on the part of the incomes of farmers, manual wage earners, and lower salaried workers to advance as rapidly as the volume of consumers' goods many lead to very serious and progressively cumulative consequences.

Although not a labor/IR economist per se, Harold Moulton was an institutional economist (Rutherford 2011), director of the Brookings Institution, and co-author of a three-volume research study on causes of the depression. In a lengthy summary published in Fortune magazine titled "The Trouble with Capitalism is the Capitalists," Moulton (1935) relates that the industrial sector of the relatively prosperous 1920s operated approximately $20 \%$ inside the economy's production possibility frontier and the gap was increasing because mal-distribution was funneling excessive saving-investment into capacity expansion while working class wage income and consumption spending were stagnating. He concludes,

Our capacity to produce consumer goods has been chronically in excess of the amount which consumers are able to take off the markets; and this situation is attributable to the increasing proportion of the total income which is diverted into savings channels. The result is a chronic inability to find market outlets adequate to absorb our full productive capacity.

His conclusion is that what economic theory teaches should happen is that competition forces firms to pass on productivity gains by lowering prices and raising money wages but what actually happened in the 1920s is closer to the reverse - the large industrial/banking network of corporations maintained/raised prices to consumers but maintained/cut hourly earnings to workers (e.g., by less overtime and raising the target on piece rates). Orthodox economists then and now (e.g., Robbins 1934; Rothbard 2000; Cole and Ohanian 2004) place blame for the depression on workers who over-price their labor and then refuse to cut the price to buy back their jobs. The title Moulton gives his article, therefore, correctly from an IEIR perspective shifts the blame to employers for doing the opposite of what the invisible hand directs.

President Franklin Roosevelt and Senator Richard Wagner also believed that growing mal-distribution was a major cause of the depression (Keyserling 1945; Perkins 1946; Rosenof 1975; Mitchell 1984; Kaufman 1996, 2012). Roosevelt said in a 1932 campaign speech (quoted in Fusfeld 1956, p. 205):

Our basic problem is not an insufficiency of capital. It is an insufficient distribution of buying power coupled with an oversufficient speculation in production. While wages rose in many of our industries, they did not rise proportionately to the reward to capital, and at the same time the 
purchasing power of other great groups of our population was permitted to shrink [a reference to shrinking farm incomes].

Roosevelt's position was shared by Senator Wagner, principal legislative architect of much of the New Deal recovery program and author of the National Labor Relations Act (NLRA, 1935). Wagner, like Roosevelt, believed that both the rise in income inequality and collapse into depression required fundamental structural reforms and redistribution of economic and political power from the moneyed interests to the 'forgotten man' so an economic recovery is anchored on long-term shared prosperity and not temporary monetary or fiscal stimulus - a challenge to the money-power status quo that earned both men much hatred and condemnation as socialists-communists (Perkins 1946; Stabile 2016). Their recovery-through-structural reform and power-balancing strategy is clearly stated in the preamble of the NLRA:

The inequality of bargaining power between employees who do not possess full freedom of association or actual liberty of contract, and employers who are organized in the corporate or other forms of ownership association substantially burdens and affects the flow of commerce, and tends to aggravate recurrent business depressions, by depressing wage rates and the purchasing power of wage earners in industry and by preventing the stabilization of competitive wage rates and working conditions within and between industries.

Viewed through the lens of the neoclassical/mainstream economic theory taught in universities then and now, this statement is a classic example of how bad theory leads to bad policy. Perhaps for this reason, and also ascendancy of Chicago-free market-neoliberal economic doctrine post-1980, the IEIR explanation of the Great Depression has almost completely disappeared from research and textbook literatures -- even though it formed the intellectual heart of the New Deal transformation of the 1930s and, in combination with Keynes' economics, provided for several decades after the war the guiding economic-social philosophy of one of America's two political parties. Since universities and their faculties are charged with fairly and dis-interestedly examining alternative and perhaps politically contentious science-based explanations of events, a reconsideration and elaboration of the IEIR theory of unbalanced institutional structure $\rightarrow$ growing income inequality $\rightarrow$ worsening demand/supply imbalance 
$\rightarrow$ rising probability of financial/economic crisis (all ceteris paribus) seems a deserving and overdue project.

IEIR Model Developed: The Political Economy Dimension

The IEIR model is depicted in Figure 3 (next section). It has three parts: aggregate product market, aggregate labor market, and a roof over them representing the national government. The roof (Kaufman 2010a) incorporates the political economy dimension of IEIR and its two-way connection to the market system, symbolized by the up and down arrows.

For clarity of ideas, it is important to note that the IEIR model is a close complement but not member per se of what are traditionally considered under-consumption theories of economic crises (Bleaney 1976; Allgoewer 2002). This theory strand was, however, also influential in the early New Deal, such as from Hobson and Foster and Catchings (Barber 1985). The under-consumption view draws a direct causal line from a large profit/small labor share to an economic crisis precipitated by over-investment and underconsumption. CDS explicitly reject this direct line of causation from income shares to insufficient demand (e.g., Commons 1934a: 579-81). Instead, the larger boom/bust pattern is driven by medium-longterm swings in Schumpeterian innovation and capital spending, endogenous credit expansion and contraction, and rise and fall of expected margins of profit, with failure of real wages to grow in line with productivity serving as a reinforcing maladjustment that leads over time to worsening deficient demand/excess supply imbalance. The IEIR theory, therefore, focuses more on Figure 1 than Figure 2 as the important link between inequality and crisis.

\section{The Political-Economic Nexus}

The start point for (original) institutional economics is that the economy is a structured set of market and non-market institutions, called an economic order, and it is not demand/supply that determines outcomes and behaviors but the nature of the economic order within which market and non-market institutions and their functional relations are embedded (Hamilton 1919; Samuels and Schmid 1981; Brown 2005; 
Kaufman 2017). While portions of the economic order spontaneously emerge and evolve, ultimately a nation's economy is shaped by government-established property rights, human rights, resource endowments, legal rules of the economic game, and electoral procedures. To highlight this political economy dimension, Commons titled his last book Economics of Collective Action (1950) and an earlier book on alternative employment systems Industrial Government (1921b). Also, Dunlop in Industrial Relations Systems (1958) makes the web of rules that structures the employment system the field's central theoretical focus; and Clark (1926) and Slichter (1931) frame economic outcomes as the product of social control. Thus, an IEIR model begins with the nexus between state political power, economic organization, and economic outcomes. This idea is shown in Figure 3 by the governance roof drawn over the product market in panel (a) and labor market in panel (b). The Federal Reserve Bank is highlighted immediately under the roof because of its important role.

Accordingly, mainstream economists beg the question when they start textbooks and research papers with "assume a competitive market" and draw DS curves in the middle of the diagram because the appropriate model depends on the specification of the institutional order. The institutional order, in turn, depends on the people and groups who control the nation's governance system and how they shape it to serve their individual and collective interests. If having a competitive free-market system does not suit their interests, or is not organizationally or technologically feasible, then a competitive free-market system will not exist and it seems a scientifically crude, heroic, or normatively-driven method to assume it anyway. As a concrete example, Cole and Ohanian (2004) create a competitive-based, constant-returns-to-scale dynamic stochastic general equilibrium model of the 1930s economy, fit it with data, and find that the New Deal worsened the depression. But, the conclusion is foreordained by the model's built-in assumptions, which as an empirical matter might reasonably represent the farm sector but definitely not the industrial sector.

The IEIR economists' view (also, Stiglitz 2012: Ch. 2) is that the canon of self-interest predicts that capitalists, located at the top of the economic pyramid, seek to extract large rents from the rest of society 
by gaining an institutional order of one-sided competition. An example is maximum competition and open markets on the input and cost side and restricted competition and sheltered markets on the output and sales side (Clark 1926; Slichter 1931). This idea may seem tainted with left-wing radicalism but, in fact, it is Adam Smith (1937/1776: 250) who observes, "to widen the market and narrow the competition is always the interest of the dealers." From an IEIR perspective, an exemplar of how politics is used to tip the competitive playing field in favor of the capital-owning class is the combination of high tariffs in product markets and, until 1924, open immigration in labor markets ( $\mathrm{P} \uparrow$ and $\mathrm{W} \downarrow)$.

Marx (1867) assumes the government is the agent of the ruling class and creates the institutional order to promote maximum capital accumulation and profit-making by facilitating monopolization of product markets, cutthroat competition in labor markets, and imperialist control of foreign markets. The early IEIR writers partially agreed with Marx. From their viewpoint, it was indisputable that the industrialfinancial-propertied class dominated the governments of that era and the government, in turn, organized and ran the economy to disproportionately serve their interests. Douglas (1933) states, for example, with direct reference to the Marxian thesis,

Instead of the supposedly neutral state of liberal tradition, it is claimed that we have in reality a class state which reflects the interests of the most powerful classes...The scales are therefore claimed to be weighted against the lower economic groups... That there is much truth in this indictment must be admitted and it constitutes perhaps the most fundamental challenge which the modern state must meet.

Although in Institutional Economics (1934a) Commons frames himself as "the Last Mohican of Liberalism" (p. 902), he nonetheless thought, as did Adam Smith before him (stating on p. 438 of Wealth of Nations that the "master manufacturers.... have become formidable to the government, and upon many occasions intimidate the legislature"), that government is dominated by bankers and industrialists. He states, with an obvious parallel to the financial crisis of 2008-2009, "This is American capitalism. It is an economic government of bankers more powerful than the political government” (p. 895). Stiglitz (2012: 30-31) echoes Commons' observation, stating: 
Our political system has increasingly been working in ways that increase the inequality of outcomes and reduce equality of opportunity. This should come as no surprise: we have a political system that gives inordinate power to those at the top and they have used their power not only to limit the extent of redistribution but also to shape the rules of the game in their favor.

A significant part of the IR tradition, therefore, is recognition by the field's pioneers that achieving balance and justice in employment relations first requires achieving reform in political relations so the institutional order can be appropriately structured to yield the desired outcomes in external and internal labor markets. Therefore, the first reform effort Commons engaged in at Wisconsin (1904-1905) was drafting the nation's first state civil service system so appointment and promotion in government jobs are on merit and not political patronage. Similarly, to give workers greater political voice, Commons (1907) and Douglas (1923) advocated shifting election of legislators from single winner to proportional representation. Douglas (1935a) also favored forming a new progressive party to the left of the Democratic party while the Webbs and Hobson in the UK helped form the Labour Party. Everyone in American IR thought the country needed a stronger labor movement in order to represent workers' interests in the polity and serve as a counterweight to business influence throughout government.

The IEIR form of polity, therefore, is a balanced pluralist network of competing interest groups. The central questions the polity has to answer are: what are reasonable economic outcomes for society? and what are the realistic alternatives for accomplishing this outcome? (Commons 1934a: Ch. 10). Reasonable economic alternatives and outcomes will not emerge if only one social group, be it business, organized labor, or the military, holds the power since they will structure the rules of the game and resource endowments to promote their partisan interests over others. The IEIR solution is a democratic stakeholder form of representation where all affected parties have influence and voice.

Commons generalized the concept of collective bargaining to cover all such stakeholder forms of governance, including employer-created representation plans, tripartite representation on industrial commissions and minimum wage boards, and the Board of Governors of the Federal Reserve System (Fed). For example, if the Fed is controlled by bankers, a zero inflation monetary target promotes their 
interests but, if workers control the Fed, their interests are better served by a full-employment monetary target. A reasonable outcome gives weight to both interests. In turn, if over a forty-year period real wages (one set of social interests) stagnate while stock prices and profits (a different set of social interests) boom, certainly a plausible part of the explanation may involve mainstream demand/supply shifts, such as skill-biased technological change and globalization of product and labor markets, but these factors are unlikely to have had such a large and long-term impact without also being accompanied and facilitated by a politically-engineered twist in the underlying rules of the game. Relevant examples include large cuts in marginal income and capital gains tax rates, various forms of corporate subsidy/welfare, encouragement of shareholder interests and executive compensation over stakeholder interests and mutual-gain compensation, and weakening of labor and environmental regulatory agencies/policies, which have the effect of shifting costs and responsibilities away from, and funneling national income and privileges toward, the nation's corporations and their owners-executives (Hacker and Pierson 2010).

Another form of twist that facilitates and reinforces the ability of corporations and other high-end interest groups to capture additional rents by politically reengineering the rules of the game is theoreticalideological in nature and comes from academic economics. One notes, for example, that many mainstream labor economists (e.g., Boeri and Van Ours 2008; Neumark and Wascher 2008) omit mention of political rent-seeking by business actors and wealthy elites at the top of the economic order (e.g., fastfood corporations and their industry associations, lobbyists, and large campaign contributions) and, instead, focus their critique on rent-seeking activities by workers at the low end of the order (e.g., the people working at fast-food restaurants). These workers, however, typically have only perishable and often over-supplied labor services to rent and therefore look to unions, labor law, and social safety net programs for collective support and advancement of their interests. This blind spot-normative bias in standard economics in favor of the interests of capital owners (physical, financial, human, social) over labor owners is further exacerbated by various 'do as I say and not as I do' double standards. A close-tohome example is when academic economists in their research and teaching preach the efficiency gospel 
of competitive labor markets - and pound the lectern against the distortionary, rent-seeking evils of market institutions (e.g., minimum wage laws, job security protections) - but then noticeably fail to apply this same reasoning and critique to their own university employment systems that provide tenured professors with enviable rents from a package of high pay, generous benefits, flexible hours, interesting work, and secure life-time jobs. These examples, and numerous others (e.g., modeling labor as if a commodity input valued only to the extent it produces a profit and satisfies someone's consumption experience), pointedly suggest that the scientific contest over alternative models of the economy, conflicting interpretations of the Great Depression, and assessed pros and cons of invisible-hand laissezfaire vs. socially-controlled institutional intervention, is not in fact an objective/value-free search for truth (the one-sided mainstream self-image) but, rather, an exercise normatively skewed to favor and promote what Freeman (2005) calls the 'competitive ideal.' e

The State and the Market System: Model Developed

The connection between the state in the roof and market system below the roof in Figure 3 is now developed in more detail. The discussion is framed in the context of the 1920s-1930s. At first glance the diagrams feature a perhaps daunting number of bolded points and letters but they are explained in a stepby-step process, considerably aid clear exposition of cause-effect linkages, and are elementary applications of economic principles.

\section{[Insert Figure 3 here]}

The political-economic nexus between inequality and crisis starts first in the labor market in panel (b). Different labor supply curves are shown, drawn as a function of the real wage W/P. For the moment, focus on the horizontal bottom pair. With one set of laws in the institutional order, the labor supply curve is the higher solid line and with another it is the lower dashed line (Kaufman 2010b). The position of the labor supply curve is set by workers' reservations wages which adaptively adjust upward when workers face less financial pressure to accept a low wage offer, and vice versa (per standard search models). 
Accordingly, a free market labor law regime, such as employment-at-will, no unions, and no social safety net, exposes workers to more unemployment risk with fewer back-up resources and thus results in a (ceteris paribus) lower labor supply curve. By reverse reasoning, the labor supply curve is positioned higher in a welfare state regime. An IEIR insight is that whether wages are high or low, including the compensating differentials theorized to protect the workers' interests in safe and healthful work conditions, are in part a product of social choice - hidden in orthodox economics by leaving out the governance roof, most likely tipped against the weaker party (labor) and biased toward the status quo by the Pareto welfare criterion.

A linked IEIR insight is that the capitalist employment relationship creates a structural inequality of bargaining power in both external and internal labor markets which favors the interests of employers over workers. The origin of the inequality is when the employer and job applicant sit down to negotiate terms and conditions, the worker typically needs the job more than the company needs the applicant, causing the worker to agree to lower and more 'take it or leave it' terms than otherwise. Neoclassical labor economists of the last thirty years studiously avoid touching this idea, akin to a radical hot potato, but it has respectable and common-sense origins, per Adam Smith's observation, “the masters can hold out much longer... and force the other [workers] into a compliance with their terms" (Smith 1776/1937: 66). Besides having fewer financial reserves to hold-out and a perishable labor service to sell, the worker's bargaining position is often undercut because a reserve of unemployed people in the market gives the company many willing substitutes. The effect of this inequality is to also lower the workers' reservation wage and supply curve.

The more severe is this inequality, such as for low-skill workers in an oversupplied labor market, the lower and more tipped are wages, compensating differentials, and labor conditions. An IEIR insight is that government influences the breadth/depth of unequal bargaining power by labor law regimes that shift up or down the aggregate labor supply curve. Also, capitalists, workers, and consumer-public have different interests in the government's decision and therefore jockey through the political process to get 
their favored outcome. Accordingly, labor market outcomes are a two-fold product of employer-employee bargaining position within the market (panels a and b) and within the polity (the roof).

Government, business, and social institutions, as examined in sociology and political science, introduce yet further structure and inequality into product and labor markets (Sørenson 1995; Jackson and Muellenborn 2012). The two most important sources of structure for this discussion are dualism in product and labor market structures and parallel dualism in receipt of economic rents (aka surplus). Orthodox theory, such as in popular labor economics texts, takes the competitive model as the default in labor and product markets and monopsony-monopoly as a special case. IEIR, on the other hand, takes imperfect competition as the norm with numerous forms and elements of monopoly and monopsony.

Monopsony in IEIR (Lester 1964; Kaufman 2010b) is broadly defined to include all sources of labor immobility and employer wage-making ability, such as specific human capital, company benefit programs, small number of competing employers, and positive job separation costs. These mobility constraints may result in various forms of labor exploitation, such as below-standard wages and benefits, salary compression for long-tenure employees, and segmented/discriminatory job and wage classification systems. However, in IEIR some aspects of monopoly and monsopsony are efficiency and welfare enhancing. Following Schumpeter (1939), for example, an element of monopoly gives firms the profit and market stability needed for innovation and long-term investment projects while a degree of monopsony goes with primary/high-road employment systems and high-performance human resource management practices, although frequently in the context of two-sided bilateral monopoly (Molloy and Barney 2015; Kaufman 2015).

A useful abstraction in this context is a dual market model, such as oligopoly-core vs. competitiveperiphery in the product market (Commons 1934a: 885-86; Lee and Samuels 1992) and bilateral monopoly-primary-internal vs. competitive-secondary-external in the labor market (Kerr 1977; Doeringer and Piore 1971). The dualism in labor markets is illustrated in panel (b) by, respectively, the horizontal 
and forward-sloped labor supply curves (focus on the solid lines for now). The perfectly elastic supply curve $\mathrm{LS}_{\mathrm{C} 1}(\mathrm{C}=$ competitive-external), up to the kink point (full utilization), shows that common labor is readily available to secondary-competitive firms at a going wage of $\mathrm{W}_{\mathrm{Cl}}$. The wage $\mathrm{W}_{\mathrm{C} 1}$ is relatively low; also, this labor is used in externalized employment systems in jobs requiring generic and quickly learned procedures and managed through hire-fire practices. The inelastic supply curve $\mathrm{LS}_{\mathrm{M} 1}(\mathrm{M}=$ monopsonyinternal) starts at a higher wage intercept since these workers embody education and skills from human capital investment, often with a substantial component acquired from firm-specific training and experience in internal labor markets. It slopes upward because these workers have unique productivityrelated characteristics, such as intelligence/ability, quantity/quality of human capital and experience, and motivation/personality, which are unequally distributed and therefore give some labor suppliers market leverage to command a higher wage. Indeed, characteristics for certain primary jobs, such as corporate executive, computer scientist and rock star, are very scarce and give $\mathrm{LS}_{\mathrm{M}}$ a steep nonlinear segment.

At a point in time, such as 1922 with aggregate labor demand curve $\mathrm{LD}_{22}$ (IEIR opinion was split on whether the neoclassical marginal product schedule is also the labor demand curve; this issue is noted but not further examined), secondary labor (e.g., in textile mills and lumber camps of the early 20s) gets the low(er) wage $\mathrm{W}_{\mathrm{C} 1}$ (point $\mathrm{M}$ ) while primary labor (in the welfare capitalist firms) gets the high(er) wage $\mathrm{W}_{\mathrm{M} 1}$ (point $\mathrm{N}$ ). As the economy grows, labor demand curves in both sectors (assumed identical and portrayed in a single market diagram for simplicity) shift rightward, such as from $\mathrm{LD}_{22}$ to $\mathrm{LD}_{29}$ in panel (b). The wage for secondary labor remains the same at $\mathrm{W}_{\mathrm{C} 1}$ (point $\mathrm{U}$ ) while the wage for primary labor rises to $\mathrm{W}_{\mathrm{M} 2}$ (point $\mathrm{T}$ ). If it is reasonably assumed primary workers save more than secondary workers, wealth inequality also grows - strongly if saving is near zero for secondary workers. Also, the earnings of primary workers contain economic rent of triangle $\mathrm{W}_{\mathrm{Ml}} \mathrm{NX}$ (wage above minimum supply price) while the earnings of secondary workers have zero rent (Commons 1893; Webb and Webb 1897; Hobson 1909; Kaufman 2013). Because rent is 'income received but not earned' (earned = required payment for 
productive contribution), it may be removed, such as with a progressive income tax -- strongly pushed by all IEIR economists, along with an inheritance tax -- without harming allocative efficiency.

Important to the story, as the economy grows not only does the distribution of income widen in favor of high earners but the rent component of their income also increases (Hobson 1909, 1923). Assume the labor demand curve shifts to $\mathrm{LD}_{29}$. Employment of competitive/external workers increases (point $\mathrm{U}$ ) but the wage remains $\mathrm{W}_{\mathrm{C} 1}$ and none therefore receives rent. Employment of primary/internal workers expands to point $\mathrm{T}$, the wage rises to $\mathrm{W}_{\mathrm{M} 2}$ (allowing for an element of monopsony deduction, or offset of monopsony by bilateral monopoly), all persons but the marginal last-hired receive a rent, and total rent expands to $\mathrm{W}_{\mathrm{M} 2} \mathrm{TX}$. Although not directly shown in the diagram, rent increases dramatically for the small group located on the steep nonlinear segment of the supply curve (e.g., CEOs, Wall Street financiers). The implication is that economic growth, unless strong enough to soak up the reserve of unemployed and under-employed in the secondary sector (getting to the kink point on $\mathrm{LS}_{\mathrm{C} 1}$ ), leads to rising wages and greater surplus for the top part of the workforce but (mostly) stagnant wages and no surplus (or no increase in surplus) for the middle-lower part. Growth also leads to higher profit for firms (e.g., in the secondary sector, the profit triangle $\mathrm{W}_{\mathrm{Cl}} \mathrm{ZM}$ increases to $\mathrm{W}_{\mathrm{Cl}} \mathrm{YU}$ ) and a tendency for the profit share of income to rise. The IEIR model predicts, therefore, a trend toward rising inequality in personal and functional income distributions and wealth distribution.

The dual character of the product market - described by Douglas (1935a: 233) as "half monopolistic and half competitive" -- amplifies distributional inequality. The price received by competitive sector firms (given $\mathrm{LAS}_{22}$ ), such as $\mathrm{P}_{22 \mathrm{C}}$ in the goods market in panel (a), just yields a normal profit in the long run and therefore is 'no rent' since price just covers average cost. Firms in the monopoly sector, protected by product differentiation or barriers to entry, charge a higher price, such as $\mathrm{P}_{22 \mathrm{M}}$, and earn economic profit and monopoly rent. This rent is either kept as retained earnings, usually for capital investment, or distributed to owners-shareholders as profits and interest. These owners-shareholders are concentrated in the top-end of the personal income distribution (the top $1 \%$ of U.S. households by income owned $50 \%$ of 
all stocks and mutual funds in 2013; Domhoff 2017: Table 3), thus adding to inequality among households.

The dual structure of the economy, used as a simplifying abstraction, is partly a function of exogenous variation in production systems and factor endowments. A primary sector forms around, for example, production processes with substantial increasing returns, fixed/overhead costs, and team interdependencies utilizing labor which requires substantial investment in organization-specific skills and procedures and long-term jobs to maximize discretionary effort and knowledge creation/sharing (Doeringer and Piore 1971). The dual structure is also created and strengthened, however, by selfinterested individuals and groups who use governments and social institutions (e.g., elite Ivy League universities in the U.S.; Oxbridge universities in the UK) to create and protect advantageous positions for positional goods (prestige, status) and rent-capture.

In capitalism, the commanding height of influence is wielded by owners of the critical factors of production, regarded in IEIR as entrepreneurship and credit, with the owners/controllers of credit -- the lifeblood of capitalism -- being in the \#1 position (per an earlier Commons' quote). This effect in labor markets is illustrated in panel (b) of Figure 3 by the difference between the solid and dashed supply curves. With a truly neutral government, economic and technological factors create a 'natural' dual economy and inequality of bargaining power in labor markets, illustrated by the solid supply curves. Selfinterest and the profit/rent motive, however, drive people to invest resources in manipulating government to change the rules to promote one-sided competition in their favor.

On balance, the people at the top end of society have the greatest resources and access in the political influence game and, furthermore, the most to gain from government officials and most to return as quid pro quo. The extent to which money dominates and buys influence, however, varies on a low-to-high scale across countries and over time. The US, for example, moved higher on the scale with the Supreme Court decision in Citizens United (2010) that allows individuals, organizations, and corporations to make 
unlimited election expenditures, in effect creating an electoral market to buy votes, laws, and judicial appointments. The IEIR prediction, therefore, is that absent countervailing institutional correction the owners of important companies, banks, and high-value human/social capital gradually gain more power to influence government and use it to re-structure markets so they capture more rent and shift costs on to weaker groups (Stiglitz 2012; Reich 2012). The effect is to amplify dualism and inequality of power, such as depicted by the solid and dashed supply curves in the labor market diagram.

The way this process works is illustrated in the diagram for the labor market. Rules favorable to society's high-end groups shift downward the competitive-external sector labor supply curve from solid $\mathrm{LS}_{\mathrm{C} 1}$ to dashed LS $_{\mathrm{C} 2}$ (e.g., open immigration, employment-at-will) and shift upward the primary-internal labor supply curve from solid $\mathrm{LS}_{\mathrm{M} 1}$ to dashed $\mathrm{LS}_{\mathrm{M} 2}$ (e.g., rationed professional school enrollments, reduction in income tax rates - if income effect dominates substitution effect as is general for adult men). In this case, the natural inequality of bargaining power is amplified by political reengineering of the institutional order, reducing wages and conditions and the share of social surplus going to the middle-bottom of the workforce and increasing wages, conditions, profits, and surplus share for the top strata of households.

Realistically, the polity is segmented into multiple interest groups and, indeed, this is the IEIR pluralistic vision of society and economy. But, for sake of argument, assume the polity is divided into a dualistic upper class and middle-lower class. The upper class, if cognizant of its group interests and able to organize for collective action, optimizes its share of the surplus by setting the rules of the game to yield the dashed labor supply curve $\mathrm{LS}_{\mathrm{C} 2}$ for the lower class. This supply curve yields the ‘break-even' wage $\mathrm{W}_{\mathrm{S}}$, also known as the subsistence, sustainable, or living wage. At this wage, the workers in the middlelower class segment get just enough income each year to sustain themselves for a lifetime of work and production while all the discretionary surplus goes to the upper strata (Hobson 1909; Kaufman and Gall 2015). In orthodox economics, the 'surplus-skimming' nature of this outcome is hidden because all earnings - no matter how high due to socially structured supply curves -- are portrayed as a marginal product payment for individual contribution to production. 
Inequality in the 1920s and Origin of Crisis in the 1930s: Model in Action

The next step is to use the IEIR model in Figure 3 to explain the economic events of the 1920s and 1930s as Douglas, Slichter and others interpreted them. Douglas (1935a), in particular, cites considerable empirical evidence to support the causal mechanisms and explanatory track record of his model. Key empirical features he cites for 1923 to 1929 are: productivity $\uparrow 22 \%$; money wages $\uparrow 8 \%$; unit labor cost $\downarrow$ $14 \%$; all-commodity price index $\downarrow 6 \%$ (price declines centered in agriculture and competitive industries, prices in many manufacturing industries roughly constant); total employment $\uparrow$ but manufacturing employment constant and manufacturing unemployment $\uparrow$; consumer goods output $\uparrow 31 \%$ and capital goods output $\uparrow 70 \%$; real wages $\uparrow 12 \%$ and profits $\uparrow 84 \%$; and stock market prices $\uparrow 177 \%$.

The orthodox account of the Great Depression typically starts in 1929 because it assumes external events - restrictive Federal Reserve monetary policy, supplemented by the stock market crash and SmootHawley tariff bill - were the principal source of the negative demand/supply shock. The IEIR account, partly because it is a dynamic/evolutionary theory, starts instead at the beginning of the 1920s boom and highlights the development of growing income inequality, wage stagnation and dual sector imbalances as an endogenous cause of the stock market crash and Federal Reserve's restrictive action. This account, mainstream in the pluralistic economics of the 1930s, is now in the heterodox netherworld, per Palley's (2012) observation that the institutionalist/post-Keynesian perspective "has no representation in major research universities" (p. 22). For purposes of clear exposition, the causal chain of events and linkages is broken into discrete segments.

Initial Impulse

Institutional business cycle theories have a two-part framework: initial impulse and dynamic propagation mechanism (Mitchell 1927; Clark 1934; Douglas 1935a). The impulse may be exogenous, such as a war or drought. Capitalism, however, also has an endogenous impulse mechanism. The driver of capitalism is profit and innovation (not prices and demand/supply) and short and long run cycles come 
from entrepreneurs' forward-looking profit expectations and their success at discovering new profit opportunities through devices such as new products, improved production technology, and lower cost labor (Commons 1934b: Ch. 9; Slichter 1934; Schumpeter 1939).

In 1920-21, the American economy was in a deep post-war depression; starting in 1922 (the base year depicted in Figure 3) it entered a recovery-boom phase. The principle impulse was profit-driven development à la Schumpeter of new goods, such as automobiles and radios, and accompanying mass production technology and growth in business size. For simplicity of exposition, treat these new innovations as a one-time improvement in the economy's production technology. So viewed, the innovation-technology impulse shifts the long run supply curve in Figure 3 to the right from $\mathrm{LAS}_{22}$ to $\mathrm{LAS}_{29}$. The economy can produce higher output with the same labor input, contributing to large productivity growth.

\section{Initial Product Market Position}

A feature of orthodoxy is that its core assumptions are so natural and taken for granted no one questions them or even takes notice. An example is the ubiquitous practice of starting a model at the DS equilibrium, such as in Figure 1 where $\mathrm{AD}_{22-29}=\mathrm{LAS}_{22}$ (point $\mathrm{A}$ ). [Realistically, the aggregate demand curve shifts rightward throughout the 1920s; here it is kept in one position and labelled $\mathrm{AD}_{22-29}$ to allow clear exposition of the presumed flexible price correcting mechanism in conventional theory.] This assumption presupposes the economy is competitive, at full employment, and resources are efficiently allocated per the first welfare theorem.

A reason IEIR is considered heterodox is because it assumes, in line with a century of empirical evidence, a market economy's normal position is significantly inside the production possibility frontier (LAS curve) with underutilized labor resources and plant capacity. This proposition has large ramifications for welfare analysis. That is, if IR institutions, such as unions and minimum wages, are introduced into an optimally adjusted economy on the LAS, they naturally create price distortions, resource misallocation, and a 
negative welfare verdict. If free market capitalism, however, typically operates well within the production possibility frontier, the possible efficiency loss from IR institutions may be considerably outweighed by dynamic efficiency gains if they help move the economy closer to LAS, or keep it from diverging further.

Not only did the 1920s expansion start considerably inside the LAS, a substantial output gap remained in every year through 1929 (Slichter 1931, chart on p. 6). An explanation is the dual character of the product market with a core of large firms having some monopoly-like power over price. The initial price level is not competitive $\mathrm{P}_{22 \mathrm{C}}$, therefore, but monopolistic-inflated $\mathrm{P}_{22 \mathrm{M}}$, putting the economy at point $\mathrm{C}$ on $\mathrm{AD}_{22-29}$.

\section{Initial Labor Market Position}

The demand for labor is derived from the demand for goods; thus if output is $\mathrm{Q}_{22 \mathrm{M}}$ in panel (a) of Figure 3 , it gives rise to a labor demand curve in panel (b), such as $\mathrm{LD}_{22}$ (a composite of primary and secondary labor demand). Since the legal regime for labor is laissez-faire, common labor has no social safety net and therefore a low reservation wage. Also, monopoly in the product market and monopsony in the labor market and banker-friendly zero inflation central bank monetary policy constrict employment below the competitive full employment level, further lowering common labor's reservation wage. The supply curve for the competitive-secondary sector, therefore, is the dashed supply curve $\mathrm{LS}_{\mathrm{C} 2}$ and the wage is the family subsistence ‘break-even' level $\mathrm{W}_{\mathrm{S}}$ (point $\mathrm{O}$ ).

At this wage some secondary labor remains unemployed (point $\mathrm{O}$ to the kink point) in a form of Keynesian less-than-full employment equilibrium. (With a rigid administered price, bidding down the wage increases firms' profits but not short-run sales, production, or employment.) For reasons earlier explained, the labor supply curve for the monopsony-internal sector is dashed line $\mathrm{LS}_{\mathrm{M} 2}$ with high wage (point R) and rent component in income.

AD/AS Growth over the 1920s and the Demand Challenge 
The innovation-technology shock shifts $\mathrm{LAS}_{22}$ to $\mathrm{LAS}_{29}$. The economy's capacity to produce increases from a combination of better technology, capital investment, and labor force growth. In the exposition, labor force growth is mostly abstracted. The supply side expansion is also accompanied by an increase in aggregate demand (not depicted) as firms ramp-up investment spending (I) in order to build the new capacity $(\Delta \mathrm{I} \rightarrow \Delta \mathrm{K} \rightarrow \Delta \mathrm{LAS})$. AD also increases because $\Delta$ income $\rightarrow \Delta$ consumption $(\mathrm{C})$.

Starting early in the 1920s, therefore, the economy starts on an investment-led business cycle up-phase as $\mathrm{AD}_{22-29}$ shifts rightward (not depicted). After several years, the new investment spending opportunities are exploited, capital spending falls back to the original I, the AD curve returns to its original 1922 position. (I am simplifying for ease of exposition; actually, institutionalist J.M. Clark invented the investment accelerator idea $(\mathrm{I}=\mathrm{k} \Delta \mathrm{GDP}$, where $\mathrm{k}$ is a constant $>0)$ which amplifies and endogenizes the cyclical swing in investment.) The economy, however, now has more capital stock from the $\Delta \mathrm{I}$ and higher supply capacity. The possibility exists, therefore, for an $\mathrm{AD}<\mathrm{AS}$ imbalance as the investment burst on the demand side fades while production ability is larger on the supply side. Here arises a key challenge for the capitalist economy. That is, capitalism is superior to all other known systems for generating innovation, new technology, new capital investment, and supply-side growth potential but can it also successfully create the additional income, purchasing power and spending on the demand side to take off the market at cost-recovering prices the larger supply? Alternatively framed, the expansion of supply is represented by the productivity increase $\left(\mathrm{Q}_{29}-\mathrm{Q}_{22 \mathrm{M}}\right) / \mathrm{L}$ and the economy must generate sufficient extra income to purchase the higher output per person lest $\mathrm{AD}<\mathrm{AS}$ threaten over-production and downturn.

Growth in Inequality and Wage-Productivity Imbalance

In the orthodox model, competitive market forces create enough new income, purchasing power and spending to maintain $\mathrm{AD}=\mathrm{AS}$ balance. Here is located the heart of the self-correcting mechanism embodied in Say's Law and invisible hand theorem. The new income comes from two sources. 
The first, assuming for the moment the product market is competitive, is the fall in the price level from $\mathrm{P}_{22 \mathrm{C}}$ to $\mathrm{P}_{29 \mathrm{C}}$ caused by the expansion of product supply. As long as supply exceeds demand (to the left of $\mathrm{LAS}_{29}$ ), prices fall and quantity demanded increases - a movement down $\mathrm{AD}_{22-29}$ from point $\mathrm{A}$ to $\mathrm{B}$-until a new $\mathrm{AD} / \mathrm{AS}$ equilibrium is restored on $\mathrm{LAS}_{29}$. The fall in the price level creates part of the extra purchasing power required to buy the $\mathrm{Q}_{29}-\mathrm{Q}_{22}$ c output by increasing the real income of households.

The second source of new purchasing power is the rise in factor prices, particularly a rise in the nominal wage of labor. The orthodox labor market model is the standard DS diagram and the increase in spending and output shifts the aggregate labor demand curve up a rising labor supply curve, leading to a higher equilibrium wage and wage bill (W x L). The real wage, therefore, rises from a combination of $\mathrm{P} \downarrow$ and $\mathrm{W} \uparrow$ and grows in line with productivity and provides the extra income to keep AD in balance with AS.

The dynamics in the IEIR model are considerably different. The overall price level remains constant at $\mathrm{P}_{22 \mathrm{M}}$-- a combination of constant-to-rising administered-monopoly prices in the core industrial sector and falling prices in the competitive sector (per empirical events). In the labor market, the demand curve during the investment-led boom shifts rightward from $\mathrm{LD}_{22}$ to $\mathrm{LD}_{29}$. Money wages in the competitive/secondary sector (large in terms of relative employment) remain constant with the horizontal labor supply curve $\mathrm{LS}_{\mathrm{C} 2}$. Money wages in high-end skilled/managerial-professional labor markets rise as demand shifts along the upward sloped supply curve $\mathrm{LS}_{\mathrm{M} 2}$. Combined, growth in real income for the large majority of households is anemic due to a combination of stable aggregate price level and small relative increase in the money wage.

Both functional and personal income distributions also become more unequal from 1922 to 1929. The personal distribution widens since the wage for competitive-external labor remains the same but the wage rises for primary-internal labor (points R vs. M for 1922, S vs. U for 1929). An important factor keeping the competitive sector wage constant at $\mathrm{W}_{\mathrm{S}}$ is that the overall increase in labor demand masks shrinking manufacturing sector employment due to capital-labor substitution and technological displacement. A 
result is greater technological unemployment (Slichter 1934) and downward pressure on sector-specific wages. The functional distribution likewise widens over the decade as profits surge and labor income only moderately grows -- a combination of mostly elastic labor supply and relatively inelastic labor demand (amplified by monopoly pricing).

The distributional shift to profits and high-income households encourages a rise in the saving/income ratio. Higher saving, in conventional theory, induces a fall in the interest rate and spurs more capital investment which expands spending, creates more jobs and income, and keeps AD shifting rightward in line with LAS. In the same spirit as modern supply side economic doctrine, Secretary of the Treasury Andrew Mellon (coincidentally, the third largest tax payer in the nation, behind Rockefeller and Ford) led through Congress a series of large reductions in income tax rates -- from a top marginal rate of $73 \%$ in 1922 to $24 \%$ in 1929 - in order to further promote saving and investment.

The AD-AS situation looks more threatening to the IEIR economists of this period. Greater income inequality spurs profit and saving which encourages greater capital investment and LAS expansion, greater consumption spending by high-income households on luxury goods and services, and booms in real estate and stock markets. At the same time, growing inequality restricts wage and income growth of middle/lower class families and broad-based consumption spending on the goods from mass production industry (where scale economies mean larger volume leads to lower unit costs and lower prices, assuming competition), and higher real wages. The industry composition of demand/supply twists, therefore, with much of the capacity expansion in mass production industries (automobiles the exemplar in the 1920s) while consumption spending shifts to luxury, service, finance, and craft-work industries.

Industry imbalance and overall tendency to $\mathrm{AD}<\mathrm{AS}$ are masked in the short-term, however, by stimulus to middle class consumption from two balance sheet items. The first is rising asset values from booming stock and real estate markets, the second is rising debt from credit-financed purchases. (Retail installment payment plans and residential long-term mortgages were innovations of the 1920s). On the other hand, 
the boom was not further amplified and prolonged in the 1920s by another form of debt stimulus -- deficit spending by government (balanced budgets under Republicans Coolidge and Hoover).

The Government's No-Win Position

Orthodox economists (e.g., Friedman and Schwartz 1963; Prescott 1999; Parker 2007; Ohanian 2009) claim the onset and worsening of the depression was largely the fault of government intervention and misguided policies. From the IEIR perspective, the contradictions of American capitalism in the 1920s put the government in a no-win situation and the real blame rests on inherent structural imbalances, income-wealth inequalities, and wage-price anomalies which short-circuited the system's (presumed) self-correcting mechanism and drove it to an unsupportable $\mathrm{AD}<\mathrm{AS}$ position.

Orthodox proponents point one finger of blame at the Federal Reserve Bank (Fed). If the Fed had let the money supply grow at a steady but non-inflationary rate, instability in AD could have been avoided (per the monetarist assumption of stable velocity in the quantity theory MV=PQ). This idea conflicts with the fact, however, that in the 1920s the Fed faced three incommensurable tasks. First, because the USA was on the gold standard, the Fed had to keep interest rates high enough to prevent significant gold outflow (Eichengreen 1992). But, second, with developing AD < AS imbalance from lagging C, the Fed needed to lower interest rates to prop-up spending (even if poorly targeted at capacity-expanding I) - particularly since flexible prices were not automatically getting the job done. Yet, third, the Fed needed to raise interest rates to cool down the speculative bubbles from high savings flowing into asset markets. The Fed chose to raise interest rates to rein in the asset bubbles and protect the nation's gold stock, thus further weakening AD until the imbalance tipping point came in late 1929 (Clark 1934; Slichter 1934).

The second orthodox finger of blame is pointed at government because President Hoover in late 1929 jawboned CEOs in the industrial core to maintain wage rates in order to support household purchasing power (Ohanian 2009). Critics charge the economically rational policy, given development of LD < LS in labor markets after the stock market crash, is to jawbone the CEOs to quickly lower wages so labor 
becomes cheaper to employers, job hiring resumes, and increased payrolls stimulate more consumption spending and a rebound of AD (Rothbard 2000). Both institutional economists and business leaders understood this logic but argued what may be true for an individual commodity market is not true for a national industrial economy (Keynes' fallacy of composition argument). Aggregate-level wage cuts, for example, also cut household income and spending, for as Henry Ford observed, "If you cut wages, you just cut the number of your own customers. If an employer does not share prosperity with those who made him prosperous, then pretty soon there will be no prosperity to share" (Ford and Crowther 1926: 154). Cutting wages is also self-defeating because, as another employer observed, "the result is the worker's feeling that he has been treated unfairly - which makes him sufficiently inefficient to undo the possible savings on the cost of production" (Johnson 1921: 681).

Thus, the neoclassical critics of Hoover err because macro-level wage cuts have not only a (potentially) positive effect on employment but also a negative effect, and the negative effect likely dominates (Slichter 1934: 114-24). The positive effect is on the production side where a fall in the wage W makes labor cheaper, induces hiring, lowers production cost, facilitates a fall in product price $\mathrm{P}$, which increases product demand - illustrated by the downward movement on $\mathrm{AD}_{22-29}$ from point $\mathrm{A}$ to $\mathrm{B}$. The two-part negative effect is, first, that the drop in work effort and productivity may more than offset the fall in production cost from a lower wage and, second, a lower wage reduces the aggregate wage bill and household income (given an inelastic labor demand curve - surely the case in a developing slump), and leads to further cut-back on consumption spending. The negative spending effect is illustrated in panel (a) by leftward shifts of the $\mathrm{AD}$ curve from $\mathrm{AD}_{22} \rightarrow \mathrm{AD}_{30} \rightarrow$ dashed line $\mathrm{AD}_{32}$. Falling wages, therefore, do not lead to self-correction and full employment but to a 'dog chasing its tail' syndrome of wage/price deflation and cumulative downward spiral in spending and production -- illustrated by the dynamic path A to $\mathrm{E}$ and then not to $\mathrm{G}$ but along the curved arrow to $\mathrm{H}$ on the lower demand curve. By jawboning CEOs to maintain money wages, Hoover was choosing the much smaller of two evils - making some 
production and employment uneconomic because of wage maintenance rather than to lower wages and risk a deflationary spending collapse.

Disequilibrium Dynamics and Collapse into Depression

An IEIR criticism of orthodox theory is that it makes comparative static predictions without examining the dynamic aspects of the adjustment process that connect the 'before' and 'after' equilibriums. The story just told of the movement of the economy from 1922 to 1929 and the development of AD/AS disequilibrium maladjustment is a case in point; another case in point is the movement of the economy from late 1929 to early 1933 when falling prices and wages led not to restoration of full employment (per Hayek 1933; Robbins 1934) but a deflationary downward spiral that threatened complete collapse (Commons 1934a; Keynes 1936).

As empirical context for this section (Douglas 1935a; Wolman 1933), note that from 1929-1933 the allcommodity price level $\downarrow 36 \%$; money wages $\downarrow 23 \%$; productivity $\uparrow 21 \%$; employee hours $\downarrow 53 \%$; and unit labor cost $\downarrow 36 \%$. These patterns hide, however, a marked dichotomy as prices and wages quickly started to fall after the 1929 crash in firms in competitive product markets but only began to slowly decline in the last half of 1931 in firms in oligopolistic and regulated product markets. Average weekly earnings fell $45 \%$ in bituminous coal, for example, but only $3 \%$ in utilities.

The automatic recovery process of conventional theory, as portrayed in most principles texts (e.g., Krugman and Wells 2015), is illustrated in panel (a). The stock market shock shifts $\mathrm{AD}_{22-29}$ left to $\mathrm{AD}_{30}$; at the prevailing price level (assume for exposition $\mathrm{P}_{22 \mathrm{C}}$ ) output falls from point $\mathrm{A}$ to point $\mathrm{E}$; but in response to excess supply the price level falls and the economy moves down the $\mathrm{AD}_{30}$ curve until full employment equilibrium is gained on the LAS (e.g., point G on $\mathrm{LAS}_{22}$ and on to point $\mathrm{J}$ on $\mathrm{LAS}_{29}$ ). A recession (A to E) is unavoidable but is modest and short-lived - if wages and prices are flexible and quickly drop like in the coal industry. 
Institutionalists contend this scenario is fatally flawed. Economists in the mainstream-New Keynesian tradition, for example, accept the validity of the self-correcting story in a competitive/first-welfare theorem world but argue in practice it works slowly due to various behavioral and institutional frictions and rigidities (Krugman and Wells 2015). The message, however, is orthodox - the fault is not with the competitive market model - it remains the ideal -- but the imperfect people, institutions, and governments in it. IEIR crosses into heterodox territory because it holds the self-correcting/invisible hand story is false in theory and unworkable in practice.

The orthodox story for labor markets seems falsified right from the start. Dunlop (1944) provides evidence it was not the pressure of excess labor supply (unemployment) and worker under-bidding, as pictured in the DS model of labor markets, that explains the decision of firms to cut wages but, rather, the differential pressure on their profit margins from falling prices in competitive vs. non-competitive product markets. Thus, the causal link explaining the timing and severity of wage cutting is found in the institutional structure of product markets and pressure on profit margins, not in $\mathrm{D}<\mathrm{S}$ forces of disequilibrium in labor markets and length of the queue of jobseekers (Commons 1934a: 526-53).

The standard model also ignores numerous disequilibrating sources of positive feedback (Clark 1934; Douglas 1935a). The invisible hand story depends on negative feedback; that is, if AD < AS then prices fall and $\mathrm{AD}$ increases. The IEIR economists identified downwardly rigid industrial prices as the major culprit for the failure of productivity gains to be distributed back as purchasing power to households (Douglas 1935a: 77); hence, the fault for the depression was not that labor had too high wages but capitalists had too high prices (Moulton 1935). The equilibrium-maintaining solution is for prices to steadily but very gradually come down over the entire 1920s so firms have opportunity to find offsetting productivity gains and cost reductions in order to maintain profit margins and production levels. The actual pattern, however, was relatively rigid industrial prices through the 1920s and then, after two-three years of $\mathrm{AD}$ decline, emergence of relatively large and snowballing price cuts in oligopolistic industrial sectors. Done this way, price cuts are likely to turn destabilizing (Slichter 1934). For example, firms 
cutback supply chain orders to reduce inventory stocks to protect profit margins (with deflation, inventories bring a capital loss) and, also, because demanders hold back purchases to wait for further price declines.

Wage cuts are also destabilizing, contra orthodox theory. One reason has already been given: the fall in $\mathrm{W}$ lowers AD and cuts sales and production. A second (Keynes 1936: Ch. 2) is that as W falls so does P which leaves the real wage in the labor market unchanged (in DS theory it needs to fall). Actually, between 1930-33 wages fell by approximately one-fourth but firms, now with lower production cost, followed by cutting prices by about one-third so the net effect was a perverse (viz. neoclassical theory) increase in real wages. Dunlop (1938) found this counter-cyclical movement in real wages to be the general case. Here is another dog-chasing-tail story and, also, prime illustration of why individual action in markets can fail and collective government action is needed. However, Douglas (1935a) also points out that while the real wage went up it is nonetheless incorrect for orthodox economists to blame the depression on too-high wages (or rigid wages) since with productivity growth over 1929-1932 the real unit cost of labor significantly declined.

Another destabilizing positive feedback channel important to the depression story is that the nation's credit supply also contains an endogenous pro-cyclical component. Even if the Federal Reserve keeps the money supply growing at a constant rate, total credit availability expands and contracts to accentuate booms and contractions as banks drawn down excess reserves to make loans on upswings but call in loans and build-up excess reserves in downswings (reflected in swings in velocity V).

Very important to the IEIR model is the positive feedback effect caused by fixed survival costs of families and firms (Webb and Webb 1897; Clark 1923; Kaufman 2010b; Stabile 2016). During a slump, as revenues and income fall, firms and families become increasingly squeezed by ongoing fixed cost obligations, such as minimum food, health, and housing for workers (the wage $\mathrm{W}_{\mathrm{S}}$ ). If fixed costs are large and marginal costs small, their response to $\mathrm{P} \downarrow \mathrm{W} \downarrow$ is to increase supply - by firms (e.g., farmers) to 
avoid bankruptcy and by families to avoid homelessness and destitution. Product and labor supply curves, therefore, have an asymmetric shape, as illustrated for the labor market by the kink at point $\mathrm{O}$ on $\mathrm{LS}_{\mathrm{C} 2}$ where below $\mathrm{W}_{\mathrm{S}}$ the labor supply curve (dashed line segment $\mathrm{LS}_{\mathrm{C}_{2} *}$, following the arrow) rotates to a negative slope. In this region, the self-correcting mechanism goes in reverse because falling prices and wages induce more supply on already glutted markets. For example, as wage income reaches $\mathrm{W}_{\mathrm{S}}$, employees work harder to keep their jobs, offer to work longer hours or take multiple jobs, and wives, children, retired, and students enter the labor force (the added-worker effect). Theoretically, at the subsistence income level, the labor supply curve turns unit elastic -- per a target income model of labor supply (Altman 2012) -- and the demand-supply situation in the labor market becomes dynamically unstable. (Neoclassical theory, in contrast, assumes as $\mathrm{W} \downarrow$ employees cut back work hours, or quit their jobs, for more leisure or job search, moving the economy down a forward-sloped LS.)

In sum, the IEIR perspective is that a contributing cause of the Great Depression was failure of the market system to keep purchasing power growing in line with capacity expansion through a combination of declining product prices and rising money and real wages. Then, once the depression started, the market system exacerbated the shortfall of purchasing power by unleashing a downward spiral of price and wage cuts which simultaneously caused firms to further cut back production and employment and households to further retrench on spending. When implosion of the over-leveraged and under-regulated financial sector is added to the mix, the idea that the price system's self-correcting mechanism is going to automatically stop the descent and trigger recovery -- if only government gets out of the way -- appeared to DCS as wagering the very existing of American capitalism and representative democracy on an academic theory of competitive market capitalism that only slightly resembles the real world. Thus, from the conservative/libertarian perspective, Commons, Keynes, and Roosevelt were left-wing collectivists leading the nation down the road to socialism and serfdom (Hayek 1944); from the IEIR/progressive perspective they were pragmatic reformers saving capitalism from market and moral collapse and protecting representative democracy from the social disorder that opened the door to right-wing fascist 
take-overs in Germany, Italy, and Spain (Commons 1934a: Ch. 11, "Communism, Fascism, Capitalism;" also Wapshott 2011).

Policy Response: Inequality and Crisis in the 1930s and Today

To close the paper, this section briefly considers the policy implications of the IEIR model with respect to solving the inequality/cone problem and incipient tendency for AD failure. The policy strategy adopted by Roosevelt's New Deal is considered first and then lessons are applied to America's income inequality problem of the 2010s. However, as Commons (1934a: 877) notes, "economic theory must be based on history, as well as equilibrium," and the same applies to policy implications from a theory.

In particular, the American economy is in a far different situation in the 2010s than when CDS wrote in the 1920s-1930s. At that time the United States was the rising economic and political power in the world but, today, China occupies that position and the U.S. plays the role of Britain after World War I. Britain of the early $20^{\text {th }}$ century, like the U.S. of the early $21^{\text {st }}$ century, was the declining world power suffering from imperial overreach, high inequality with anemic economic growth, shift from international creditor to debtor status, marked deterioration in government and private sector balance sheets, and a hollowing out of manufacturing from an overvalued currency and loss of international competitiveness.

\section{New Deal Policy for Restoring Shared Prosperity}

Conceptually, the productivity-wage cone in Figure 1 can be narrowed either by lowering the productivity growth line or raising the (median) growth line of real wages. The latter, in turn, can be accomplished by lowering consumer prices or raising money wages or other forms of labor compensation.

Lowering productivity growth makes everyone poorer and is a non-starter option. From an IEIR perspective, increasing real wages through deflation of the price level is also likely to make everyone poorer from recession, for reasons described. The remaining option to narrow the cone is increase in the growth rate of money wages (broadly defined). Money wages, in turn, can be pulled up by market forces 
or pushed up by institutional forces. Commons indicates the IEIR preference is to rely where possible on market-pull but willingness to use institutional-push as either complement or substitute. He states on this matter (Commons 1934a: 875),

If the profit-motive, in the field of economics, can be enlisted in the program of social welfare, then a dynamic factor, more constructive than all the others, is enlisted. It is an appeal to the businessman to get rich by making others rich, and, if he does not respond, then to appeal to collective action.

Upward market pull on wages comes from stronger AD which shifts product and labor demand curves rightward enough to soak up the unemployed so firms voluntarily raise wages to retain current employees and recruit new employees. Upward institutional push on wages, on the other hand, comes from IR policy actions, such as higher/expanded minimum wages, union bargaining coverage, and social safety net programs, that shift upward firms' cost curves and the economy's short-run AS curve (not shown in Figure 3). Both $\mathrm{AD}$ and IR policy instruments raise wages and narrow the cone but the former, ceteris paribus, is preferable because it expands profits and employment while the latter tends to squeeze profits and reduce employment. However, in the 1930s CDS concluded that a successful AD expansion program also requires a synergistic complement of expanded IR and social welfare initiatives (Slichter 1936: 211).

CDS applauded Roosevelt for refusing to wait for automatic recovery and switching to methods of managed recovery (Commons 1934a: 887-900; Douglas 1935a: 95). As the New Deal unfolded, they nonetheless concluded the package of programs was in some ways counter-productive and in other ways inadequate. Core parts of the New Deal IR program were a mandated minimum wage, unemployment and old age insurance programs, and expanded collective bargaining. Each of these measures raises wages, expands non-wage compensation, creates wage floors, and increases labor's power in wage determination. From an IEIR perspective, these actions are desirable because they help stop deflation, more fully cover social costs of labor, end exploitation (with large unemployment, real wages are often below marginal product), create stronger automatic stabilizers, reduce inequality in the personal earnings distribution, and shift national income from capital to labor. They also have positive effects on 
productivity (Altman 2012), such as reduced turnover, an efficiency wage effect and fewer work stoppages, and higher wages not only raise production cost but also consumer spending.

However, just as CDS were skeptical of the efficacy of wage cutting to bring about recovery, so too were they skeptical that the reverse strategy of wage raising would by itself be successful (Slichter 1934: 30; Douglas 1935a: 223-29). From their perspective, the structural rebalancing of bargaining power and creation of a social safety net for workers is needed to reduce problems of inequality and wage stagnation but has to be complemented by an even stronger program of monetary/fiscal stimulus so that the expansion of production and employment from a rightward shift in the AD curve more than offsets the contractionary effect from the cost-induced upward shift in the economy's AS curve (including higher taxes on businesses and households for social insurance contributions).

Since the economy was so far below potential output in 1933-1935, CDS (Douglas 1935a: 137) thought inflation effects would be minimal, particularly since firms would be able to offset the cost push effect of higher labor cost with cost economies from increased volume. The need to expand AD was heightened by other aspects of the New Deal program which CDS supported as part of the structural attack on unbalanced income distribution. An example is reversing the income tax cuts of the 1920s to restore much greater progressivity in marginal rates. However, the higher income tax payments cause a leakage from $\mathrm{AD}$ that needs to be offset by other short-run spending injections. With regard to longer-term saving, investment, and labor supply decisions, on the other hand, the higher income tax rates are largely nondistortionary because much of top-end income takes the form of economic rent.

Another reason for AD expansion is that a portion of the National Industrial Recovery Act (NIRA, 1933) encouraged monopoly pricing in product markets which acted as a negative shock undermining AD and employment expansion (Douglas 1935a: 324-50). The NIRA's cartelization of product markets, and Agricultural Adjustment Act's curtailment of crop and livestock production, were strongly opposed by CDS as counterproductive monopolistic restrictions. This position, at first glance, appears contradictory 
with their support of greater unionism and legal regulation in labor markets. However, given CDS's diagnosis that structural monopoly kept prices too high and rigid in product markets while structural inequality of bargaining power kept wages too low in labor markets, their position is consistent. (Institutionalist Gardner Means made this idea well-known in the 1930s with his theory of administered prices; see Lee and Samuels (1992). The monopoly part of the NIRA was pushed by a diverse coalition favoring business planning, industrial self-government, and European-type corporatism and social democracy (e.g., Gerard Swope of General Electric, Veblenian Rexford Tugwell, and Senator Richard Wagner).

From the perspective of CDS (Slichter 1936: 209), the most important shortcoming in the New Deal program was failure to inject enough additional purchasing power so $\mathrm{AD}$ expands sufficiently to not only absorb the policy-induced increase in labor cost (and prices) but also promote strong economic recovery with expanding production, employment, and renewed capital investment. By 1933 the economy had tremendous excess production capacity and, also, little room for interest rates to further drop, so expansionary monetary policy was largely sidelined (Douglas 1935a: 117). Likewise, other countries were too much in depression for the devaluation of the dollar in 1933 to have much stimulus effect on exports. The only potent policy instrument left was government deficit spending but Roosevelt was philosophically committed to balanced budgets (Barber 1985). Thus, despite the much publicized New Deal public works programs (e.g., Works Project Administration, Civilian Conservation Corps), the actual size of deficit spending relative to the huge shortfall in $\mathrm{AD}$ was small and inadequate. Without enough offsetting Keynesian-type AD stimulus, the cost-raising IR structural reform part of the New Deal exerted a restrictive effect on recovery during the 1930s. It unfortunately took World War II to boost government spending enough to restore full employment. Then, after the war, the nation experienced a thirty year IEIR/Keynesian golden era with strong growth, much-reduced inequality, real wages advancing with productivity growth, and small threat of competitive undercutting from foreign rivals.

Implications for Policy in the 2010s 
A worsening wage-productivity cone problem developed in the 1920s, first, because of widening in the personal distribution of income caused by a combination of weak wage pull-up from expansionary AD forces, declining wage push-up from institutional forces (decade-long drop in union density), and large cut in income tax rates for high earners, and, second, because of increase in the capital share of income relative to the labor share as strong productivity growth and stagnant wages resulted in booming profits. Much the same constellation of forces accounts for the rising cone problem and growth of income inequality in the U.S. since the 1970s, but with added features that have considerably prolonged and worsened the process and thus portend a much deeper and prolonged correction.

The cone divergence and income inequality problems worsened in the 1920s because the natural endogenous dynamic identified above was amplified by that era's version of neoliberal, free-market, and supply-side economics. The same triplet of policies, interacting with the endogenous inequality dynamic, has created a similar cone problem since 1980 (Palley 2012; Reich 2012; Lavoie and Stockhammer 2013). When President Reagan entered office, the top income tax rate was $70 \%$ and when President G.W. Bush left office in early 2009 the rate had been cut to $35 \%$. Likewise, the real value of the minimum wage was \$9.07 when Reagan entered office and fell to \$6.94 in Bush’s last year, union density among wage/salary workers fell from $23 \%$ to $12 \%$, and the proportion of unemployed receiving unemployment insurance fell from $38 \%$ to $32 \%$. Similarly, the Congressional Budget Office (2015) estimates that actual output fell below potential output (a measure of AD deficiency) in twenty-five years and above potential output in eight years between 1980-2013 (mostly in the late 1990s), with cumulated negative gaps more than triple the cumulated size of positive gaps.

Closing the cone requires a similar combination of $\mathrm{AD}$ wage pull up, institutional wage push up, and increase in high-end income tax rate rates as initiated during the 1930s. But, as pointed out above, the economic and political situation facing the U.S. in the 2010s is quite different. Consideration of these contextual factors points to the sobering conclusion that no New Deal-type package of reforms can solve the cone/inequality problem in the 2010 s without high risk of tipping the U.S. economy into the next 
recession/depression. But, at the same time, if the cone problem is not addressed the accumulating imbalances will also likely precipitate a future recession/depression. The U.S. economy has entered, therefore, what appears to be the no-win end phase of the current wage-stagnation/credit cycle where the structural imbalances have deteriorated to the point the next major downturn, absent an offsetting boost to demand/supply (e.g., a new technology or product innovation), appears locked-in and a matter of time.

As described earlier, closing the productivity-wage cone requires on the institutional side some combination of higher minimum wage, expanded social safety net programs, and larger union density, along with restoration of higher marginal income tax rates (and inheritance taxes) on top-end households. These actions, on balance, raise cost and reduce profit margins for firms and need to be offset by expanded AD. In the 1930s, expansionary monetary policy could not generate the needed stimulus but expansionary deficit spending could because the government's balance sheet was in excellent condition from a prior decade of budget surpluses. Likewise, the U.S. did not need to worry about a large leakage of demand into extra imports or appreciation of the dollar in the 1930s because international trade was a small part of total GDP and FDR had devalued the dollar and taken the country off the gold standard.

In the 2010s, on the other hand, expansionary monetary and fiscal policies have been pushed to their limits to stop the 2008-2009 crisis and restore modest growth while an overvalued dollar and mercantilist trade policies of China and other countries cause American AD stimulus to have a weak effect on domestic production because a significant portion of extra consumption spending and corporate profits leak out as commodity imports, foreign direct investment, and financial market asset speculation. With monetary and fiscal policies in the U.S. largely tapped-out (e.g., key interests rates have been kept extraordinarily low by massive quantitative easing of the money supply while fiscal deficits have been so large the national debt has doubled in the last decade), a massive accumulated international debt position from three decades of budget and trade deficits, emergence of new bubble tendencies in financial and real estate markets, and slowing growth in Asia and weak performance in Europe, the American economy is particularly susceptible to downturn from any cutback initiated by falling profit expectations from $\mathrm{AD}<$ 
AS. The trigger for the next crisis, therefore, is likely some negative AD/AS shock, much like the stock market crash of late 1929, with the combination of factors cited above - including the long-term hollowing out of middle-lower class spending power from three decades of rising inequality, stagnating wages, and export of goods-producing jobs -- leading to deeper cumulative collapse, as in 1930-1932. The hugely troubling difference between then and now is that the American government in the 2010s is in a far weaker position to rescue the system as 'spender of last resort.'

The role of labor unions, mentioned but not discussed to this point, is important but also contradictory. As a general principle, CDS supported laws protecting workers rights to join unions and collective bargaining, partly for democratic workforce governance but also to reduce inequality of bargaining power in labor markets (Commons 1934a: 588; Douglas: 1935a: 212; Kaufman 2007). However, in the 1920s they became disillusioned with a large part of the American labor movement due to its outmoded craft union structure, sclerotic leadership, and oppositional stance to unitarist 'goodwill' employment programs (Leiserson 1929; Slichter 1929). CDS therefore shifted priority to solving the cone problem with the triplet of management-led welfare capitalism (with high-commitment wages, job security, and gainsharing), creating and pushing up wage floors and social safety nets with labor law and social insurance; and preventing destructive business cycles and unemployment with macroeconomic stabilization programs (Draper, Commons, Lescohier, and Lewisohn 1925; Commons 1927; Whalen 1993; Kaufman 2003). Further, CDS concluded labor unions typically pinch profit margins more than labor laws and social insurance programs and for this reason are second best. Yet, when the depression developed, the welfare capitalist model failed and, to stop wage cutting and then reflate wages and AD, CDS shifted back to strong support for unions, per their encouragement of the Wagner Act (Kaufman 2016a). Nonetheless, Douglas (1935a) and Slichter (1934) give paradoxically little discussion to unions as instruments for narrowing inequality and the productivity-wage cone even though wage policy gets entire chapters in their books. 
After WWII, the combination of Keynesian full employment demand management and strong union bargaining power led to a secular increase in union wage premiums, loss of competitiveness in heavily unionized industries, and cost-push inflation pressures (Blanchflower and Bryson 2007; Freeman 2007; Hirsch 2012). With this record in mind, little doubt exists that a return to a pre-1970 union density rate of $25 \%-35 \%$ would significantly narrow the productivity-wage cone, per comparison to the cone in other countries with higher union density (BLS 2012: Chart 3:12). On the other hand, one also has to worry that the downside for the American economy, in the context of a decentralized and non-coordinated bargaining system and substantial trade exposure, would be significant harm to competiveness, jobs, and growth performance. Yet, without a strong labor movement, who or what is going to effectively represent workers' interests in the political process so corporations, bankers, and rich don't use their dominance of government to further tilt the rules of the game (tax policy? health care? environment?) toward top-end inequality and rent-seeking (Hacker and Pierson 2011)? Commons (1934a: Ch. 11; 1950) considers the trade-offs and alternatives and concludes a strong labor movement is the better social choice because, without it, capitalism endogenously drifts toward plutocracy, crisis-producing economic imbalance, political conflict and class polarization, and potential for an American form of fascism (the 'Weimar scenario' in Palley 2012).

\section{Conclusion}

Early IEIR writers concluded the \#1 cause of poor employment relations a century ago was the macroeconomic trilogy of significant reserve army of unemployed, corrosive effect of high and worsening income inequality, and destabilizing boom/bust cycles. Recognizing that solving a problem first requires understanding and explaining it, they worked out a dynamic disequilibrium model with the employment relationship and wage-productivity nexus at the core. Other important parts include the conflicting logics of exchange in markets and production in organizations, dualistic market structure of competition and monopoly/monopsony; an economic-political nexus with tendency toward elite control by corporations, financiers, and large property owners; inequality of bargaining power favoring employers in external and 
internal labor markets; skewed generation and distribution of economic rents to owners of scarce resources and social/political privilege; and secular tendency toward worsening aggregate demand/supply imbalance from profit-led investment spending outpacing wage-led consumption spending.

This model in large part informed Franklin Roosevelt's diagnosis of the onset and worsening of the Great Depression and shaped the New Deal strategy he and IEIR advisors adopted for solving the debacle. Indeed, an integrated version of IEIR in labor markets and Keynesianism in product markets, sometimes called after the war Social Keynesianism, served as the guiding economic doctrine of American governments until the 1980 election of Reagan and triumph of Friedman and Hayek over Keynes and Commons (Wapshott 2011; Galbraith 2016). Not coincidentally, the return of free-market/supply-side economics also brought with it the same pre-1930s pattern of growing inequality and divergence of wage and productivity growth and eventual collapse in 2008 into crisis and near-depression. Advocates of the free market were as surprised by the onset of crisis in 2008 as they were in 1929 and, in response, said as little as possible until the storm passed or pointed the finger of blame at government and associated liberal/labor interest groups for the traditional sins of obstructing competition, interfering with demand/supply and the invisible hand, and enabling distortionary rent-seeking by the usual suspects (e.g., Mulligan 2012; Allison 2013).

A popular adage is that people who do not learn from history are destined to repeat it, and the latest bubble of free-market fundamentalism seems an affirmative example. So viewed, the Friedman-HayekLucas era of the last three decades is only the latest chapter in an orthodox book of Panglossian science fiction and utopian individualism. This story, taught in universities around the world, features highly imperfect creatures - selfish, aggressive, status-seeking, semi-rational humans - who originally live in a Hobbesian world of war, predation, and bare subsistence but, as if by an invisible-hand miracle, are led out of darkness simply by following perfect-tending, zero-cost competitive market price signals -- a heaven-sent free lunch when all other coordination modes (e.g., firms and management) require expensive set-up and operating costs -- to spontaneously trade themselves to a best-of-all-possible worlds of 
maximum freedom, material goods, and life satisfaction in an idealized form of a global-scale Oriental bazaar. This story, built on impressive but equally improbable logic, became the gospel two hundred years ago when Ricardo triumphed over Malthus and Sismondi and compelling competitive market logic triumphed over compelling empirical facts - starting with the fifteen year post-Napoleonic depression (1815-1830) which Ricardo and laissez-faire true-believers blamed on government interference with free trade in goods and child labor.

The specific intent of this paper is to uncover and develop the long-buried and forgotten part of the early institutional-industrial relations literature dealing with labor markets, income inequality, and wageproductivity dynamics. The broader aim is to provide a paradigm vision in labor economics and general economics for a more realistic, relevant, explanatory, and humanistic alternative to the dominant neoclassical framework of competitive demand-supply labor markets, automatic self-correcting/invisiblehand/full-employment equilibrium, and first and second welfare theorems. But, if nothing else, the paper at least disproves the long-time caricature that original institutional economics is an empty project of no theory or anti-theory (Coase 1998; Boyer and Smith 2001; Kaufman 2017) - although this too could be a hollow accomplishment since the two-century orthodox response to heterodox challenge, if not caricature and misrepresentation, is avoidance, silence, and the blind eye.

\section{References}

Allgoewer, Elizabeth. 2002. "Underconsumption Theories and Keynesian Economics: Interpretations of the Great Depression.” Discussion Paper 2002-14. University of St. Gallen.

Allison, John. 2013. The Financial Crisis and Free Market Cure. New York: McGraw Hill.

Altman, Morris. 2012. Economic Growth and the High Wage Economy. London: Routledge.

Atkinson, Glen, and Theodore Oleson, Jr. 1998. "Commons and Keynes: Their Assault of Laissez-Faire.” Journal of Economic Issues, 32(December): 1019-30. 
Barber, William. 1985. From New Era to New Deal: Herbert Hoover, the Economists, and American Economic Policy, 1921-1933. Cambridge: Cambridge University Press.

Berlingieri, Giuseppe, Blanchenay, Patrick, and Chiara Criscuolo. 2017. The Great Divergence(s): The Link between Growing Productivity Dispersion and Wage Inequality. OECD STI Policy Note (May).

Bivens, Josh, and Lawrence Mishel. 2015. "Understanding the Historic Divergence between Productivity and a Typical Worker's Pay.” Report, Economic Policy Institute (September 2, 2015).

Blanchflower, David, and Alex Bryson. 2007. "What Effect Do Unions have on Wages Now and Would Freeman and Medoff be Surprised?" In J. Bennett and B. Kaufman, (eds.), What Do Unions Do? A Twenty Year Review, pp. 79-113. New Brunswick: Transaction.

Bleaney, Michael. 1976. Underconsumption Theories: History and Critical Analysis. New York: Lawrence and Wishart.

Boeri, Tito, and Jan Van Ours. 2008. The Economics of Imperfect Labor Markets. Princeton: Princeton University Press.

Boyer, George, and Robert Smith. 2001. "The Neoclassical Tradition in Labor Economics.” Industrial and Labor Relations Review 54(2): 199-223.

Brown, Christopher. 2005. "Is there an Institutional Theory of Distribution?” Journal of Economic Issues 39(4): 915-31.

Bureau of Labor Statistics, U.S. Department of Labor. 2012. Charting International Labor Comparisons, 2012 ed. Washington: GPO.

Clark, John M. 1923. Studies in the Economics of Overhead Costs. Chicago: University of Chicago Press. 
1926. Social Control of Business. Chicago: University of Chicago Press.

1934. Strategic Factors in Business Cycles. New York: National Bureau of Economic

Research.

Coase, Ronald. 1998. “The New Institutional Economics.” American Economic Review, 88(May): 72-74.

Cole, Harold, and Lee Ohanian. 2004. "New Deal Policies and the Persistence of the Great Depression: A General Equilibrium Analysis.” Journal of Political Economy, 112(4): 779-816.

Commons, John. 1893. The Distribution of Wealth. New York: Macmillan.

1907. Proportional Representation, $2^{\text {nd }}$ ed. New York: Kelly.

1921b. Industrial Government. New York: Macmillan.

1924. Legal Foundations of Capitalism. New York: Macmillan.

. 1925. "The Stabilization of Prices and Business." American Economic Review, 15(1): 43-52.

1934a. Institutional Economics: Its Place in Political Economy. New York: Macmillan.

1934b. Myself. Madison: University of Wisconsin Press.

1950. The Economics of Collective Action: Madison: University of Wisconsin Press.

Congressional Budget Office. 2015. Why CBO Projects that Actual Output will be Below Potential Output on Average. Washington: CBO.

Council of Economic Advisors. 2015. Economic Report of the President. Washington: GPO.

Davidson, Paul. 2007. John Maynard Keynes. New York: Palgrave Macmillan.

Devine, James. 1983. "Underconsumption, Over-investment and the Origins of the Great Depression." Review of Radical Political Economics, 15(2): 1-27. 
Doeringer, Peter, and Michael Piore. 1971. Internal Labor Markets and Manpower Analysis. Lexington: Lexington Books.

Domhoff, G. William. 2017. "Wealth, Income, and Power." http://www2.ucsc.edu/whorulesamerica/power/wealth.html.

Douglas, Paul 1923. “The Necessity of Proportional Representation.” International Journal of Ethics, 34(1): 6-26. . 1933. “An Economist's Idea of Good Government.” Annals of the American Academy of Political Science, vol. 169; 184-192. . 1935a. Controlling Depressions. New York: Norton. . 1935b.

Draper, Ernest, Commons, John, Lescohier, Don, and Sam Lewisohn. 1925. Can Business Prevent Unemployment. New York: Knopf.

Dunlop, John. 1938. “The Movement of Real and Money Wage Rates.” Economics Journal, 48(September): 413-34. 1944. Wage Determination under Trade Unions. New York: Macmillan. 1958. Industrial Relations Systems. New York: Holt.

Eichengreen, Barry. 1992. Gold Fetters: The Gold Standard and the Great Depression, 1919-1939. New York: Oxford University Press.

Ford, Henry, and Samuel Crowther. 1926. Today and Tomorrow. Garden City, NJ: Doubleday Page.

Freeman, Richard. 2005. "Labor Market Institutions without Blinders: The Debate over Flexibility and Labor Market Performance.” International Economics Journal, 19(2): 129-45. 
2007. America Works: Thoughts on an Exceptional U.S. Labor Market. New York: Sage

Foundation.

Friedman, Milton, and Anna Schwartz. 1963. A Monetary History of the United States, 1867-1960. Princeton: Princeton University Press.

Furman, Jason, and Peter Orszag. 2015. "A Firm-Level Perspective on the Role of Rents in the Rise of Inequality.” Paper presented at Columbia University (October 16).

Fusfeld, Daniel. 1956. The Economic Thought of Franklin D. Roosevelt and the Origin of the New Deal. New York: Columbia University Press.

Galbraith, James. 2016. Inequality: What Everyone Needs to Know. Oxford: Oxford University Press.

Hacker, Jacob, and Paul Pierson. 2011. Winner Take All Politics. New York: Simon \& Schuster.

Hamilton, Walton. 1919. “The Institutional Approach to Economic Theory.” American Economic Review, 9(March): 309-18.

Hayek, Friedrich. 1933. Monetary Theory and the Trade Cycle. London: Jonathan Cape. . 1944. The Road to Serfdom. Chicago: University of Chicago Press.

Hirsch, Barry. 2012. “Unions, Dynamism, and Economic Performance.” In C. Estlund and M. Wachter (Eds.), Research Handbook on the Economics of Labor and Employment Law, 107-45. Northampton: Elgar.

Hobson, John. 1909. The Industrial System: An Inquiry into Earned and Unearned Income. London: Longmans, Green. . 1923. The Economics of Unemployment. London: Macmillan. 
Jackson, Gregory, and Tim Muellenborn. 2012. "Understanding the Role of Institutions in Industrial Relations: Perspectives from Classical Sociology." Industrial Relations, 51(S1): 472-500.

Johnson, George. 1921. “What I've Learned about Business since 1920.” System, 15(6): 679-83.

Kaufman, Bruce. 1993. The Origins and Evolution of the Field of Industrial Relations in the United States. Ithaca: ILR Press.

. 2003. "John R. Commons and the Wisconsin School on Industrial Relations Strategy and Policy." Industrial and Labor Relations Review, 57(1): 3-30.

. 2007. "Historical Insights: The Early Institutionalists on Trade Unionism and Labor Policy.” In J. Bennett and B. Kaufman (eds.), What Do Unions Do? A Twenty Year Perspective, 46-78. New Brunswick: Transaction.

. 2010a.” The Theoretical Foundation of Industrial Relations and its Implications for Labor Economics and Human resource Management." Industrial and Labor Relations Review 64(1): 74 -108 .

.2010b. "Institutional Economics and the Minimum Wage: Broadening the Theoretical and Policy Debate.” Industrial and Labor Relations Review 63(3): 427-53.

. 2012. "Wage Theory, New Deal Labor Policy, and the Great Depression: Were Government and Unions to Blame?" Industrial and Labor Relations Review 65(3): 501-32.

. 2013. “Sidney and Beatrice Webb's Institutional Theory of Labor Markets and Wage Determination.” Industrial Relations 52(3): 765-91. . 2015. “The RBV Theory Foundation of Strategic HRM: Critical Flaws, Problems for Research and Practice, and an Alternative Economics Paradigm." Human Resource Management Journal, 25(4): 516-40. 
. 2016. "Experience with Company Unions and Their Treatment under the Wagner Act: A Four Frames of Reference Analysis.” Industrial Relations 55(1): 3-39.

. 2017. "The Origins and Theoretical Foundation of Original Institutional Economics

Reconsidered." Journal of the History of Economic Thought 39(3): 293-322.

, and Michael Barry. 2014. "Building IR Theory on the Founders' Principles with Empirical Application to Australia." Industrial and Labor Relations Review, 67(5): 1203-34.

, and Gregor Gall. 2015. “Advancing Industrial Relations Theory: An Analytical Synthesis of British-American and Pluralist-Radical ideas." Relations Industrielles/Industrial Relations 70(3): 407-431.

Kerr, Clark. 1977. Labor Markets and Wage Determination. Berkeley: University of California Press.

Keynes, John. 1936. The General Theory of Employment, Interest, and Money. London: Macmillan.

Keyserling, Leon. 1945. “Why the Wagner Act?” In L. Silverberg (ed.), The Wagner Act: After Ten Years, pp. 5-33. Washington: Bureau of National Affairs.

Krugman, Paul, and Robin Wells. 2015. Macroeconomics, $4^{\text {th }}$ ed. New York: Worth.

Lavoie, Marc, and Engelbert Stockhammer, 2013. Wage-led Growth: An Equitable Strategy for Economic Recovery. Geneva: ILO.

Lee, Frederick, and Warren Samuels. 1992. The Heterodox Economics of Gardiner C. Means: A Collection. Armonk: M.E. Sharpe.

Leiserson, William. 1929. “Contributions of Personnel Management to Improved Labor Relations.” In Wertheim Lectures on Industrial Relations, 125-64. Cambridge: Harvard University Press.

Lester, Richard. 1964. Economics of Labor, $2^{\text {nd }}$ ed. New York: Macmillan. 
Lucas, Robert. 2004. “The Industrial Revolution: Past and Present.” Economic Education Bulletin, 44(8): 1-8.

Marx, Karl. 1867/1906. Capital, Vol. 1. New York: Modern Library.

Mas-Colell, Andreu, Whinston, Michael, and Jerry Green. 1995. Microeconomic Theory. New York: Oxford University Press.

Mitchell, Daniel. 1984. “Inflation, Unemployment, and the Wagner Act: A Critical Appraisal,” Stanford Law Review, 38(April): 1065-95..

Mitchell, Wesley. 1927. The Business Cycle: The Problem and Its Setting. New York: National Bureau of Economic Research.

Molloy, Janice, and Jay Barney. 2015. "Who Captures the Value of Human Created with Human Capital? A Market-Based View. Academy of Management Perspectives 29(3): 309-25.

Moulton, Harold. 1935. “The Trouble with Capitalism is the Capitalists.” Fortune (November): 77-81, 166-82.

Mulligan, Casey. 2012. The Redistribution Recession. Oxford: Oxford University Press.

Murphy, Kevin, and Robert Topel. 2016. "Human Capital Investment, Inequality and Economic Growth.” NBER Working Paper 21841. Cambridge: NBER.

Neumark, David, and William Wascher. 2008. Minimum Wages. Cambridge: MIT Press.

Ohanian, Lee. 2009. "What - or Who - Started the Great Depression?” Journal of Economic Theory 144(6): 2310-35.

Osberg, Lars. 2014. "Can Increasing Inequality be a Steady State?" OECD Statistics Working Papers, 2014/01. Paris: OECD. 
Palley, Thomas. 2012. From Financial Crisis to Stagnation. Cambridge: Cambridge University Press. . 2016. "Inequality, the Financial Crisis and Stagnation: Competing Stories and Why They Matter." Real World Economic Review, 74: 1-19.

Parker, Randall. 2007. The Economics of the Great Depression. Northampton: Elgar.

Perkins, Francis. 1946. The Roosevelt I Knew. New York: Viking.

Piketty, Thomas. 2014. Capital in the Twenty-First Century. New York: Belknap.

Prescott, Edward. 1999. "Some Observations on the Great Depression.” Federal Reserve Bank of Minneapolis Quarterly Review, (Winter): 25-29.

Reich, Robert. 2012. Beyond Outrage. New York: Vintage.

Robbins, Lionel. 1934. The Great Depression. New York: Books for Libraries Press.

Romer, Christina. 2013.” Lessons from the Great Depression for Policy Today. Teach-in on The Great Depression and World War II.” Norman: University of Oklahoma.

Rosenof, Theodore. 1975. Dogma, Depression, and the New Deal: The Debate of Political Leaders over Economic Recovery. Port Washington, WA: Kenikat.

Rothbard, Murray. 2000. America’s Great Depression, $5^{\text {th }}$ ed. Auburn: Ludwig Mises Institute.

Rutherford, Malcolm. 2011. The Institutionalist Movement in America, 1918-1947. Cambridge: Cambridge University Press.

Samuels, Warren, and A. Allan Schmid. 1981. Law and Economics: An Institutional Perspective. Boston: Kluwer-Nijhoff.

Schumpeter, Joseph. 1939. Business Cycles. New York: McGraw Hill. 
Sherk, James. 2013. "Productivity and Compensation: Growing Together.” No. 2825. Heritage Foundation.

Slichter, Sumner. 1929. "Current Labor Policies of American Industries.” Quarterly Journal of Economics 43(3): 393-435.

1931. Modern Economic Society. New York: Holt.

1934. Towards Stability: The Problem of Economic Balance. New York: Holt.

. 1936. “The Adjustment to Instability.” American Economic Review, 26(March): 196-213.

Smith, Adam. 1937/1776. An Inquiry into the Nature and Cause of the Wealth of Nations. New York: Random House.

Sørenson, Aage. 1996. “The Structural Basis of Social Inequality.” American Journal of Sociology, 101(5): 1333-65.

Stabile, Donald. 2016. The Political Economy of the Living Wage: Progressives, the New Deal, and Social Justice. New York: Macmillan.

Stiglitz, Joseph. 2012. The Price of Inequality. New York: Norton.

Webb, Sidney, and Beatrice Webb. 1897. Industrial Democracy. London: Longmans, Green 1923. The Decay of Capitalist Civilization. Westminster: Fabian Society.

Wapshott, Nicholas. 2011. Keynes Hayek: The Clash that Defined Modern Economics. New York: Norton.

Whalen, Charles. 1993. "Saving Capitalism by Making It Good: The Monetary Economics of John R. Commons." Journal of Economic Issues, 27(4):1155-79. 
. 2008. “Toward 'Wisely Managed' Capitalism: Post-Keynesian Institutionalism and the Creative State.” Forum for Social Economics, 37(1): 43-60.

Wisman, Jon. 2013. "Wage Stagnation, Rising Inequality and the Financial Crisis of 2008." Cambridge Journal of Economics, 37(4): 921-45.

Wolman, Leo. 1933.Wages During the Depression. New York: NBER.

Yellen, Janet. 2016. "The Outlook, Uncertainty, and Monetary Policy.” Address at the Economic Club of New York. Washington: Federal Reserve Bank. 
Figure 1. Growth of Productivity and Real Wages, United States

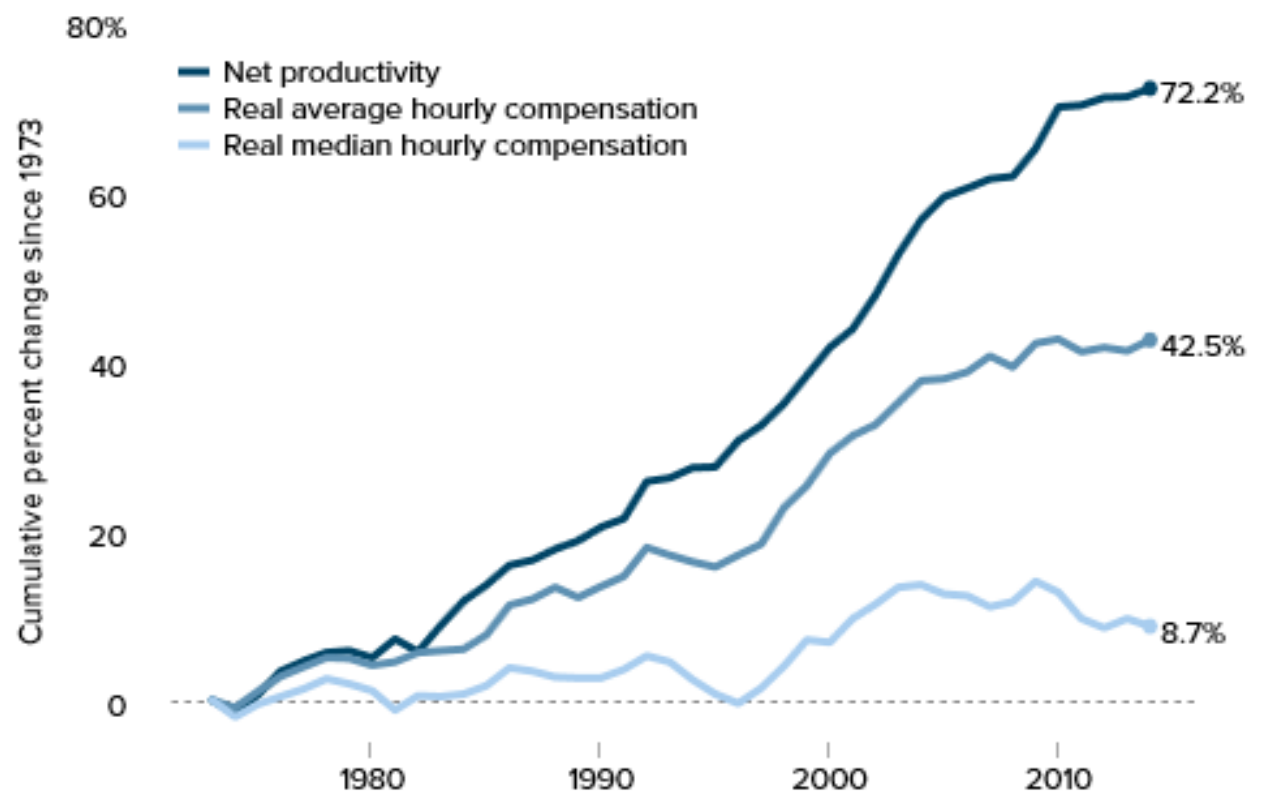

Source: Bivens and Mishel, 2015.

Figure 2

The Evolution of the Shares of the Top 1 Percent in Different Countries

A: Top 1 Percent Income Shares in English-speaking Countries (U-Shape)

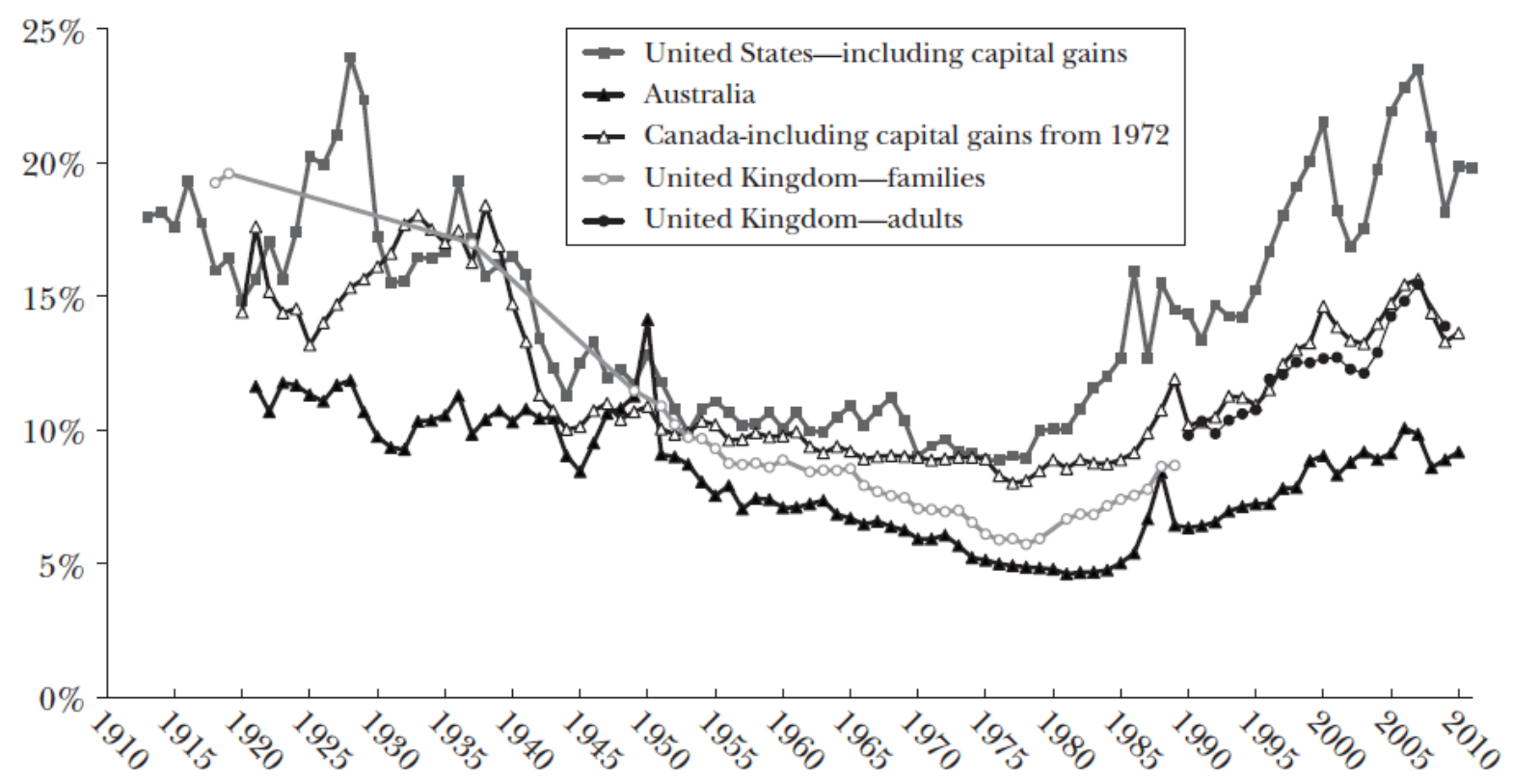

Source: Osberg, 2014 


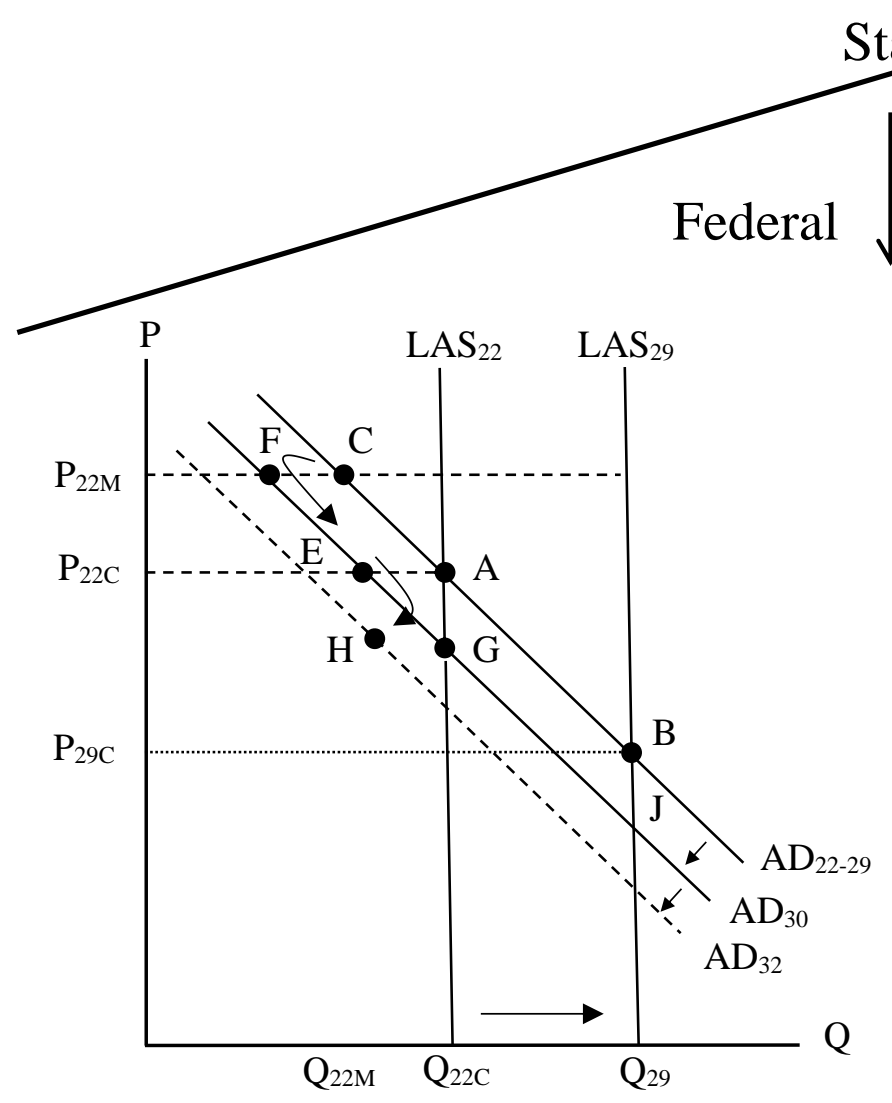

(a) Product Market
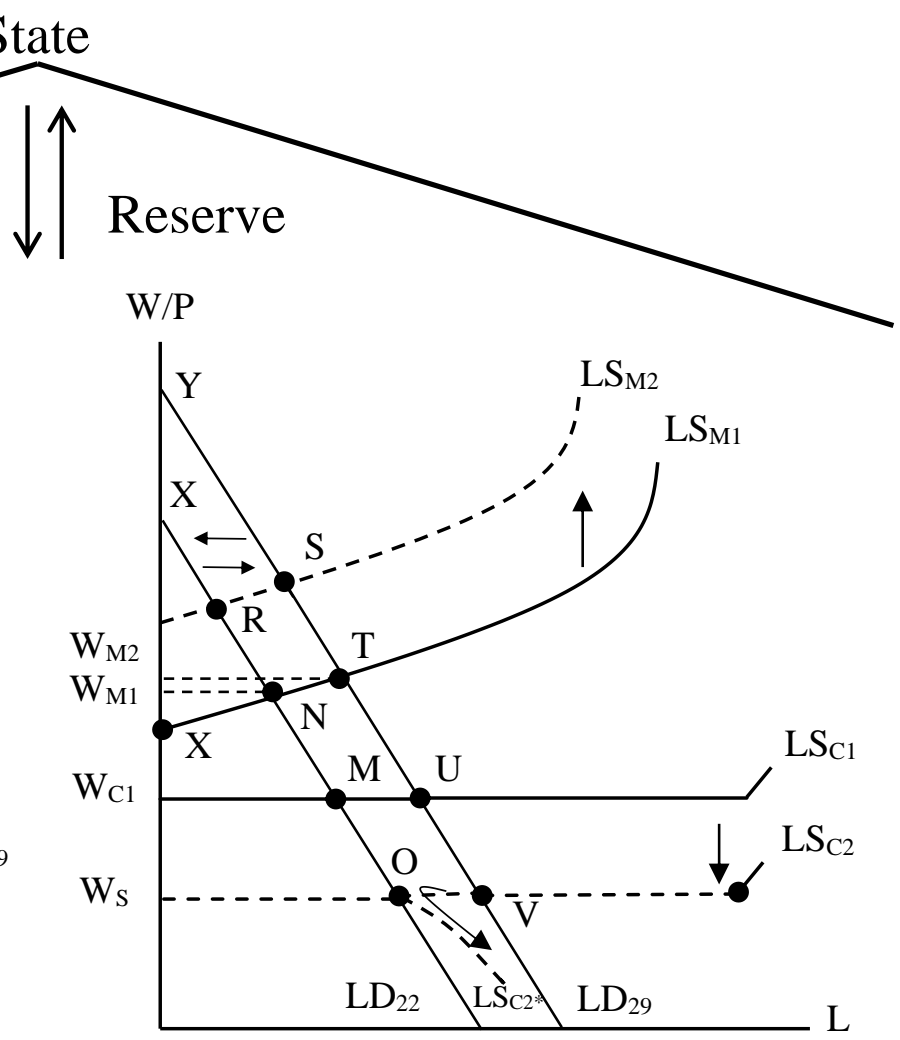

(b) Labor Market

Figure 3. IEIR Model: Events of 1920s-1930s Explained 